\title{
Frasnian-Famennian (Upper Devonian) transition in the northern hemisphere (NE Laurussia and NE Siberia) - an overview
}

\author{
Andrey V. Zhuravlev \& Elena V. Sokiran
}

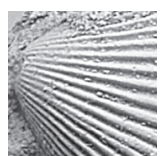

\begin{abstract}
There is high similarity in sedimentation and taxonomic composition and stratigraphic succession of conodonts and brachiopods across the Frasnian-Famennian (F-F) transition in low- and mid-latitude realms of NE Laurussia and Siberia. This uniformity suggests the presence of low environmental gradients between $10^{\circ} \mathrm{S}$ and $40^{\circ} \mathrm{N}$ of the northern hemisphere corresponding to tropical and subtropical climatic zones. The changes in taxonomic diversity in these marine faunas occurred gradually throughout the Frasnian, and were paired with similar, mostly carbonate facies settings, marked by rare development of the Kellwasser-type organic-rich deposits. Moderated ecological effect of the rapid climatic shifts during the F-F crisis is also noteworthy, especially for the shelly benthos, with an exception of the Lilliput effect. $\bullet$ Key words: Frasnian-Famennian boundary, northern hemisphere, conodonts, brachiopods, facies changes, Laurussia, Siberia.
\end{abstract}

Zhuravlev, A.V. \& Sokiran, E.V. 2020. Frasnian-Famennian (Upper Devonian) transition in the northern hemisphere (NE Laurussia and NE Siberia) - an overview. Bulletin of Geosciences 95(4), 419-439 (12 figures, 2 appendices). Czech Geological Survey, Prague. ISSN 1214-1119. Manuscript received March 18, 2020; accepted in revised form July 10, 2020; published online August 30, 2020; issued November 15, 2020.

Andrey V. Zhuravlev, N.P. Yushkin Institute of Geology Komi SC UrB RAS, 54 Pervomayskaya St., Syktyvkar, 167000 , Russia; micropalaeontology@gmail.com - ElenaV. Sokiran, Department of Stratigraphy petroleum provinces, All-Russia Petroleum Research Exploration Institute (VNIGRI), 28 Salova St., Saint-Peterburg, 192102, Russia

The Frasnian-Famennian (F-F) boundary interval corresponds to the significant biotic crisis in the middle Palaeozoic (McGhee 2013, Stanley 2016). During the late Frasnian most marine organisms of the tropical realm were affected by the stepwise extinction or diversity reduction due to a decrease in speciation rates (see Stigall 2010 for discussion). Among the terrestrial organisms, the extinction of land plants took place in the Late Pal. rhenana conodont Zone, and none of the known fossil tetrapod groups survived the end of the Frasnian (McGhee 2013). Modern overviews of the biotic and abiotic changes at the F-F transition were done by Ma et al. (2016), Qie et al. (2019) and Carmichael et al. (2019).

In contrast to the well-studied F-F transitions in the palaeotropical realm and southern hemisphere (North America, Western Europe, northern Africa, Australia, and China) this interval is less known in the northern hemisphere (Eastern Europe, Urals, northern Siberia). According to palaeoclimatic reconstructions (Boucot et al. 2013) the East European Craton (eastern Laurussia) and shelves of the Uralian Strait were located in the equatorial (tropical) realm at the latest Frasnian-earliest Famennian. The Siberia palaeocontinent, excluding its southern part, was in a subtropical climatic zone, even if located at midlatitudes (Fig. 1B).
The F-F transition beds of north-eastern Laurussia, known from the central and south-eastern parts of the East European Platform (EEP), Pechora Platform (PP), northern Urals, and Pai-Khoi, represent a wide spectrum of facies. Northern Siberia sections (north of Siberian Platform and Kolyma-Omolon Uplift) contain the F-F transition in shallow-water and deep-water facies (Yolkin et al. 2006, Gagiev 2009, Yazikov et al. 2013). Thus, the most representative of the F-F transition sequences that characterize north-eastern Laurussia ( 9 sections and boreholes) and northern Siberia (5 sections) were selected for testing palaeolatitudinal and facies gradients in the $\mathrm{F}-\mathrm{F}$ transition in the northern hemisphere (Fig. 1).

The aims of the article are the following: to analyze distribution of conodonts and brachiopods in the F-F transition in various facies of the tropical and northern subtropical realms of the northern hemisphere; and to evaluate facies and palaeolatitudinal gradients in the F-F fauna turnover in the northern hemisphere in respect of local and regional versus global causes of the biotic crisis. In this context, the regional impact of the highlighted Viluy Large Igneous Province (LIP) of Siberia was first mentioned.

The F-F transition was characterized by the transgressive-regressive sequences reported in different regions. Sandberg et al. (1988) considered biotic and lithological 
records of the global event in the palaeotropical realm, and according to these authors, the changes of conodont associations were attributed to a eustatic rise followed by an abrupt eustatic fall preceding the F-F mass extinction. Sea level rise at the Pal. linguiformis Zone was detected in the Betic Cordillera, Spain (Rodríguez-Cañero \& MartínAlgarra 2014), and Appalachian Basin (Lash 2017). The presence of post-Frasnian regression is indicated in the eastern Laurussia basin by a regional unconformity in the shallow-water shelf facies. The unconformity corresponds to stratigraphical gap from (?) Pal. linguiformis Zone up to Pal. delicatula platys Zone in some regions, exemplified by East European Platform (Alekseev et al. 1996). In contrast, sea level fall at the terminal Frasnian (Pal. linguiformis Zone) is reported in Iran (Gholamalian 2007), Moravia (Hladil 2002), and some regions of South China (Ma et al. 2016). Thus it is difficult to separate tectonic and eustatic sea level changes around the F-F transition. Hallam \& Wignall (1999) suggested that tectonics plays a significant role in regional and local sea level changes in western Laurussia.

The term "Kellwasser (KW) Crisis", based on classic outcrops of the Rhine Slate Mountains and Harz Mountains, is commonly accepted to describe both the upper Frasnian Kellwasser black shale horizons (lower LKE, upper - UKE) and the corresponding global anoxic events (see summary in Gereke \& Schindler, 2012). In particular, the transgression acme at the latest Frasnian (Pal. linguiformis Zone) was accompanied by shelf anoxia (Chen \& Tucker 2003; Bond \& Wignall 2008; Carmichael et al. 2014, 2019; Crasquin \& Horne 2018). The signatures of anoxia are well developed mainly in the deep-water shelf environment, however absent or weak in the shallow-water carbonate platform and epicratonic basins, with some local exceptions reported by Bond et al. (2013) and Carmichael et al. (2014). There are three alternative models for the anoxia event. The first one postulates turnover of oceans bringing deep anoxic water onto the shelves (Joachimski et al. 2001, Chen \& Tucker 2003). The second model supposes surface and shelf water eutrophication resulting in hypoxia/anoxia accompanied by climate cooling pulses (e.g. Carmichael et al. 2014, Huang et al. 2018). Cooling at the F-F transition was supposed by a number of researchers on the basis of diverse data (e.g. Copper 1998, Hallam \& Wignall 1999, Lash 2017). According to oxygen isotope ratios in conodont apatites (Huang et al. 2018), the extreme greenhouse climate, with surface seawater temperatures above $30^{\circ} \mathrm{C}$, was interrupted by two cooling episodes of $\sim 7^{\circ} \mathrm{C}$ during the KW events. The third model proposes development of mid water column oxygen minimum zone between oxygenated surface and deep waters, expanding onto the shelves in response to enhanced primary productivity (Crasquin \& Horne 2018).

A recent hypothesis of a primary trigger considers consequence of large-scale volcanism possibly coupled with the effects of Eovariscan tectonism (Racki 1998a, Pujol et al. 2006, Kravchińsky 2012, Ricci et al. 2013, Winter 2015, Ma et al. 2016, Racki et al. 2018). The Viluy LIP is considered as possible source of catastrophic volcanic eruptions that triggered the end-Frasnian mass extinction (Kravchińsky 2012, Ricci et al. 2013, Racki et al. 2018). The revised F-F boundary date ( $371.86 \pm 0.08 \mathrm{Ma}$ according to Percival et al. 2018) does fall within age uncertainty of a late Frasnian pulse in the Viluy LIP (Percival et al. 2018). Thus there is just indirect evidence of coincidence between flood basalt eruption and the F-F biotic crisis, contrary to arc magmatism suggested by Winter (2015).

\section{Material and methods}

This study is based on new and published lithological and palaeontological data from the East European Platform, northern Urals, Pai-Khoi, the East Siberian Platform, and north-east Siberia (Pershina \& Tsyganko 1980; Alekseeva et al. 1996; Yudina et al. 2002; Deulin 2006; Yolkin et al. 2006; Ovnatanova \& Kononova 2008; Zhuravlev 2008, 2016; Gagiev 2009; Tsyganko 2011; Yazikov et al. 2013; Zatoń et al. 2014; Zhuravlev et al. 2015; Ovnatanova et al. 2017). The new data comprises lithological and palaeontological (brachiopods and conodonts) information from the sections of the East European Platform (two sections) and Pai-Khoi (two sections).

Illustrated conodonts and brachiopods are reposited in the Geological Museum of the Institute of Geology Komi SC UrB RAS, Syktyvkar, Russia; collection number 713.

Records of $\delta^{13} \mathrm{C}_{\text {org }}$ in conodont elements of three taxa (Icriodus, Jablonnodus, and Mitrellataxis) were studied from the East European Platform sections (Kamenka Quarry and Russkiy Brod Quarry). Separated conodont elements of good preservation were washed with ethanol and distilled water and then used for analysis of carbon isotope values with DELTAVAdvantage mass spectrometer equipped with the Thermo Electron Continuous Flow Interface (ConFlo III) and Element Analyzer (Flash EA 1112). The $\delta^{13} \mathrm{C}_{\text {org }}$ values are reported relative to the PDB standard. Isotope analyses were performed at the CKP "Geonauka" of Institute of Geology Komi SC UrB RAS (Syktyvkar, Russia). International standard USGS-40 (L-Glutamic acid) was used. The precision of the $\delta{ }^{13} \mathrm{C}_{\text {org }}$ value is $\pm 0.15 \%$. The $\delta^{13} \mathrm{C}_{\text {org }}$ values in conodont elements are considered as a proxy of position in the trophic web and feeding specialization (Zhuravlev \& Smoleva 2018).

The maps by Scotese (2016) compose palaeogeographic framework of this study. The plate-tectonic reconstruction model of Scotese (2016) is based on palaeomagnetic reference frames for 410-250 Ma. The model used palaeomagnetic data to constrain the palaeolatitudinal positions and rotation of plates. These 

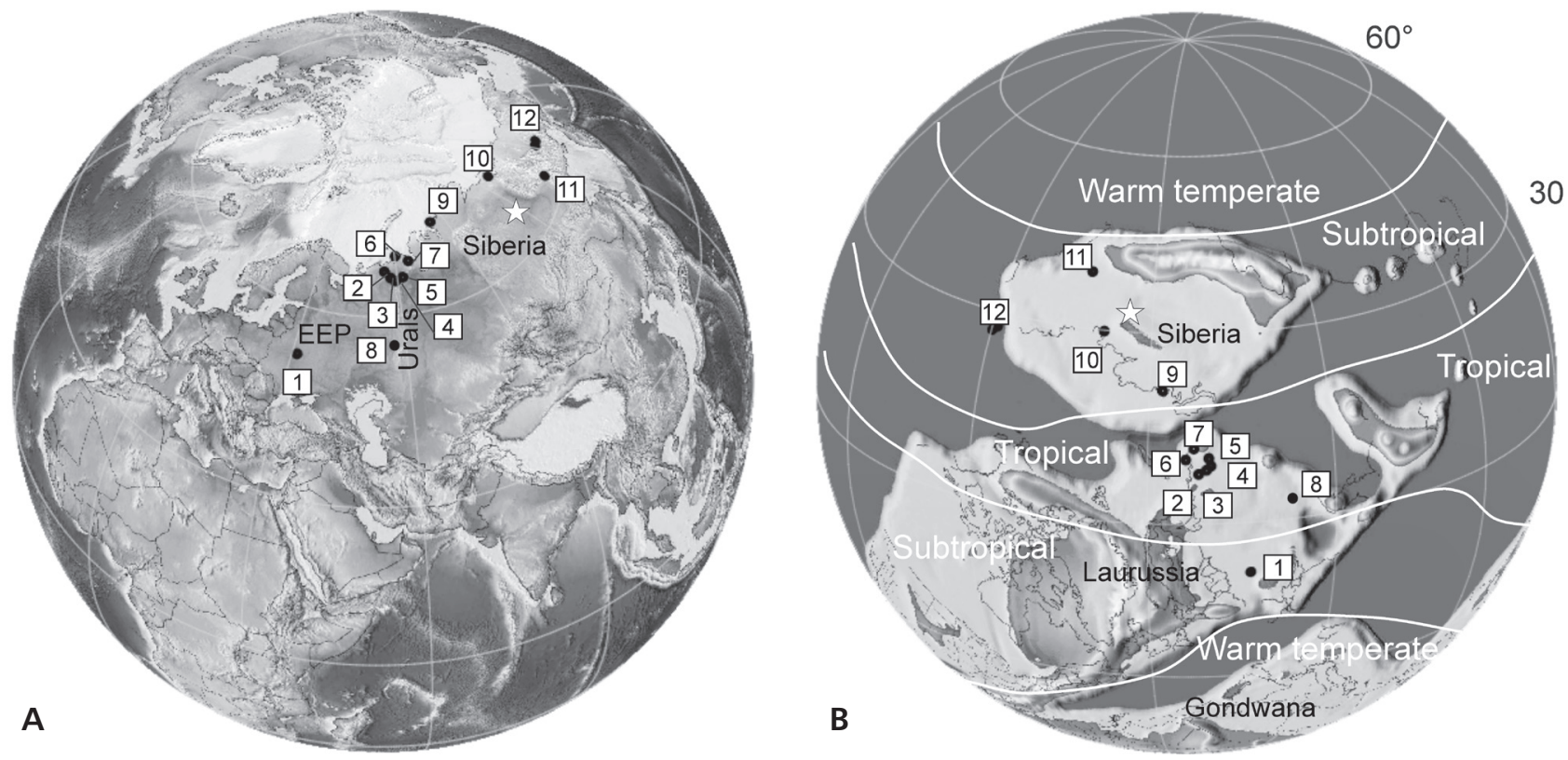

Figure 1. Locations of the Frasnian-Famennian boundary sites (A - recent geography; B - Late Devonian geography based on Scotese 2016, climatic belts after Boucot et al. 2013). Viluy LIP is marked by star. Sites: 1 - Voronezh Uplift, East European Platform; 2 - north-western part of the Pechora Platform; 3 - eastern part of the Pechora Platform; 4 - Syvyu River section, Subpolar Urals; 5 - Lemva River basin, Polar Urals; 6 - northern Pai-Khoi; 7 - Kara River section, Southern Pai-Khoi; 8 - Volga-Ural Uplift; 9 - Domba River section, Taimyr Peninsula, northern Siberia; 10 - Stolb section, Lena River, northern Siberia; 11 - Khandyga River section, Sette-Daban Ridge, north-eastern Siberia; 12 - Kolyma Uplift, north-eastern Siberia.

plate-tectonic reconstructions form the basis of the model of palaeoclimate evolution developed by Boucot et al. (2013). The palaeoclimate reconstructions proposed by these authors are based on the distribution of lithologic indicators, such as distribution of bauxites, laterites, kaolinites, evaporites, calcretes, coals, and tillites.

The north-eastern Laurussia craton and shelves of Uralian Strait were located in the equatorial realm, but the north-eastern part of the Siberia palaeocontinent was located in the subtropical realm in the late Frasnianearly Famennian (Boucot et al. 2013). The sites under consideration at the F-F transition were distributed within wide palaeolatitudinal interval ranging from $10^{\circ} \mathrm{S}$ up to $40^{\circ} \mathrm{N}$, and were located along the palaeoclimatic gradient from an equatorial climate to a subtropical climate (Fig. 1).

Geochemical data are unavailable for most of the regions under consideration. Some geochemical information was obtained from the East European Platform (Kamenka Quarry) and North Urals (Syv'yu River) sections (Yudina et al. 2002, Krawczyński et al. 2004).

\section{North-eastern Laurussia}

\section{East European Platform}

Epicratonic shallow-water environment. - Shallow-water sequences of the F-F transition are represented by successions of the central-western part of the EEP (Voronezh
Uplift, Russkiy Brod Quarry and Kamenka Quarry; Zatoń et al. 2014) and Volga-Ural Uplift (Ovnatanova \& Kononova 2008) (Fig. 1). The upper Frasnian interval, roughly correlated with Lower Pal. rhenana-Pal. linguiformis conodont zones, is composed of a lateral transition from a restricted marine carbonate facies through carbonate shoreface to offshore facies in the central-western part of the EEP (Voronezh Uplift sections) (Fig. 2). Latest Frasnian conodont associations are dominated by polygnathids (see Appendix 1). The uppermost part of the Pal. linguiformis Zone and lower part of the Famennian (through Pal. delicatula platys Zone) were eroded due to the early Famennian regression. Overlying deposits are represented by sandstones of the nearshore facies (Russkiy Brod Quarry section) and by clayey limestone and clay alternation in the shoreface facies (Kamenka Quarry section) (Fig. 2).

The lowermost Famennian conodont associations, comprising polygnathids, spathognathids (Mehlina), icriodids, Jablonnodus, Mitrellataxis, and rare palmatolepids characteristic of the Pal. minuta minuta-Pal. glabra pectinata conodont zones (see Appendix 1). The abrupt changes in the fauna composition may be consequence of absence of the data corresponding to the gap comprising the interval from the upper Pal. linguiformis Zone to Pal. minuta minuta conodont Zone.

In the uppermost Frasnian of the Voronezh Uplift (Livny Horizon, Russkiy Brod and Kamenka quarries) the brachiopods are rare (Ljaschenko 1959). The lower 
Russkiy Brod section

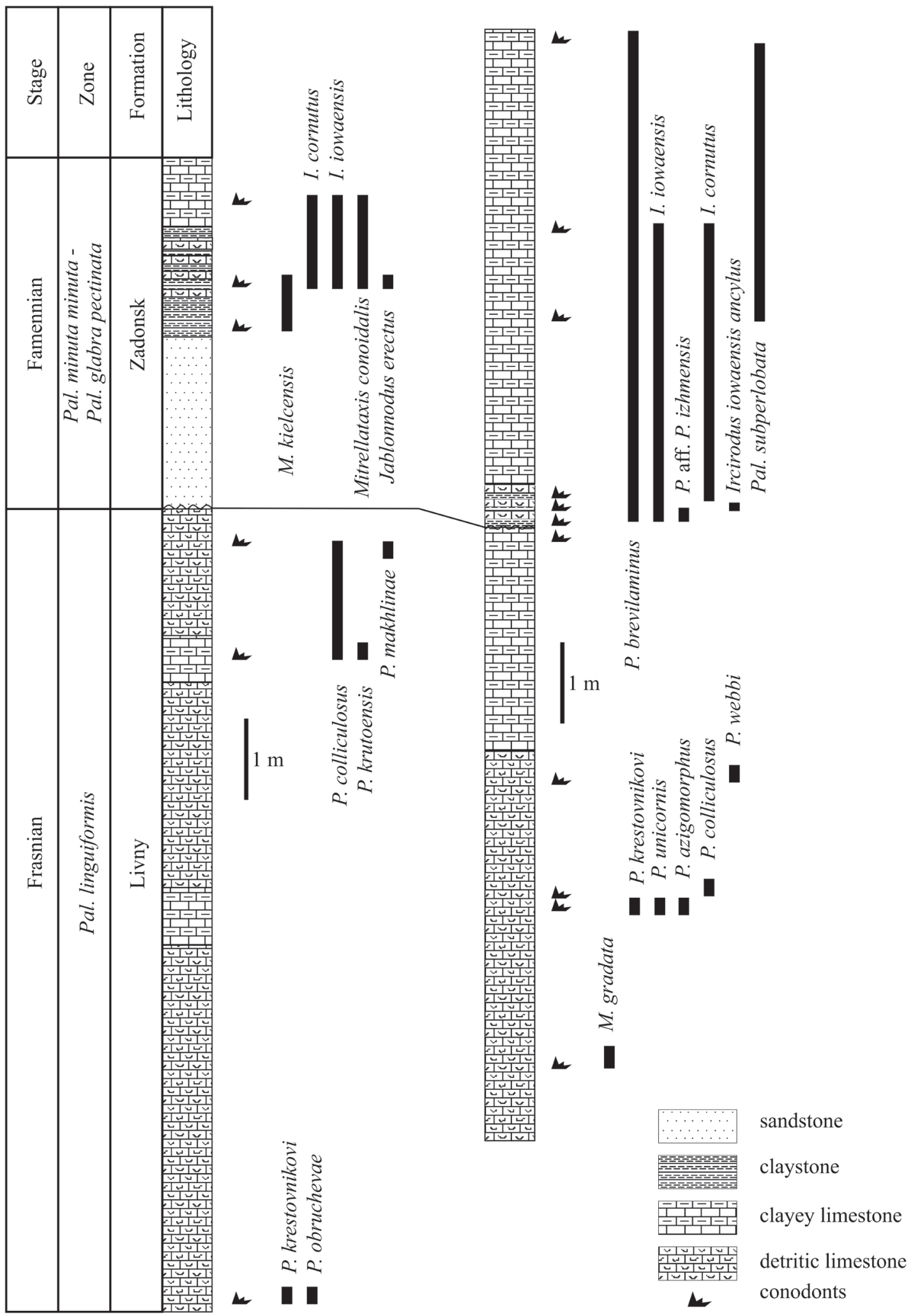

Figure 2. Lithology and conodont distribution in the F-F epicratonic shallow-water sequences of the Voronezh Uplift, East European Platform. Abbreviations: P. - Polygnathus, Pal. - Palmatolepis, M. - Mehlina, I. - Icriodus. 


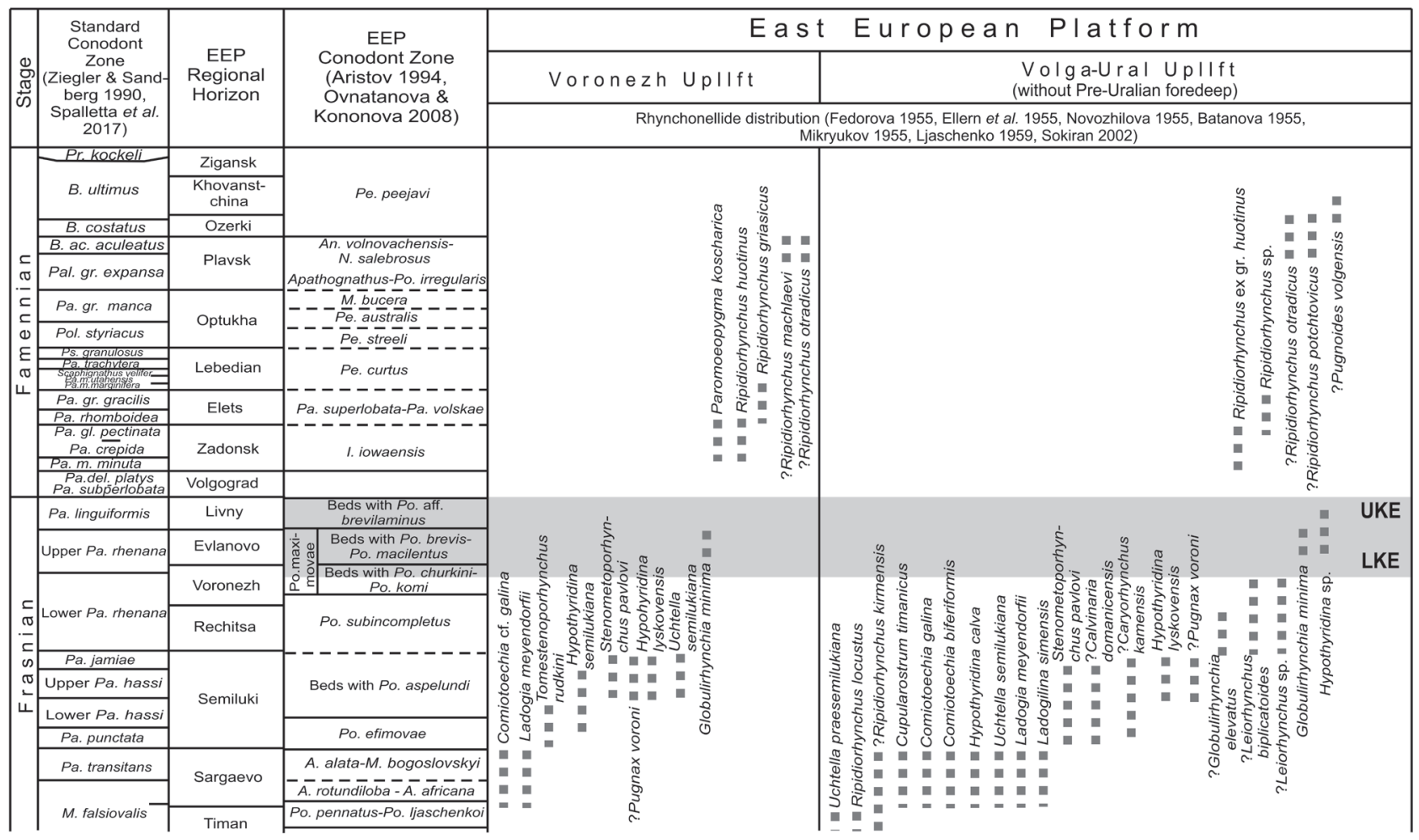

Figure 3. Distribution of rhynchonellid brachiopods in the F-F interval of the East European Platform. Grey belt corresponds to the KW Crisis: LKE - Lower Kellwasser Event; UKE - Upper Kellwasser Event.

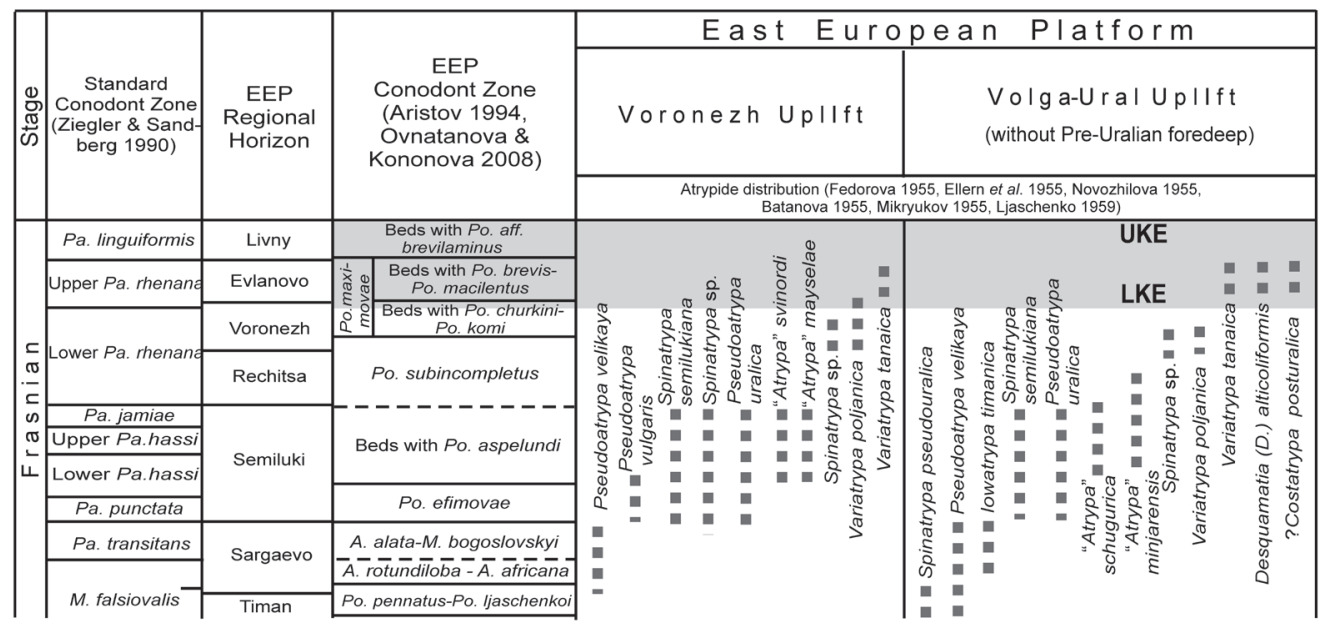

Figure 4. Distribution of atrypid brachiopods in the F-F interval of the East European Platform. For explanations see Fig. 3.

Famennian (Zadonsk Horizon, Russkiy Brod and Kamenka quarries) brachiopods are more abundant and diverse (Ljaschenko 1959) (see Appendix 2). The shallowwater sequences of the Volga-Ural Uplift and Voronezh Uplift are similar and characterized by almost the same brachiopods (Figs 3-5).

Epicratonic deep-water environment. - The deep-water facies of the Volga-Ural Uplift (southeastern part of east of
EEP) are distributed within the Kama-Kinel palaeotrough system. The latest Frasnian interval is represented by micritic bituminous limestones with layers of cherty shales and cherts. The deposits contain conodonts of the Pal. linguiformis Zone (Ovnatanova \& Kononova 2008) (Appendix 1). The lowermost Famennian is similar in lithology (alternation of dark bituminous clayey limestones and siliceous shales) and contains conodont fauna of Pal. subperlobata-Pal. delicatula platys zones (Ovnatanova \& 


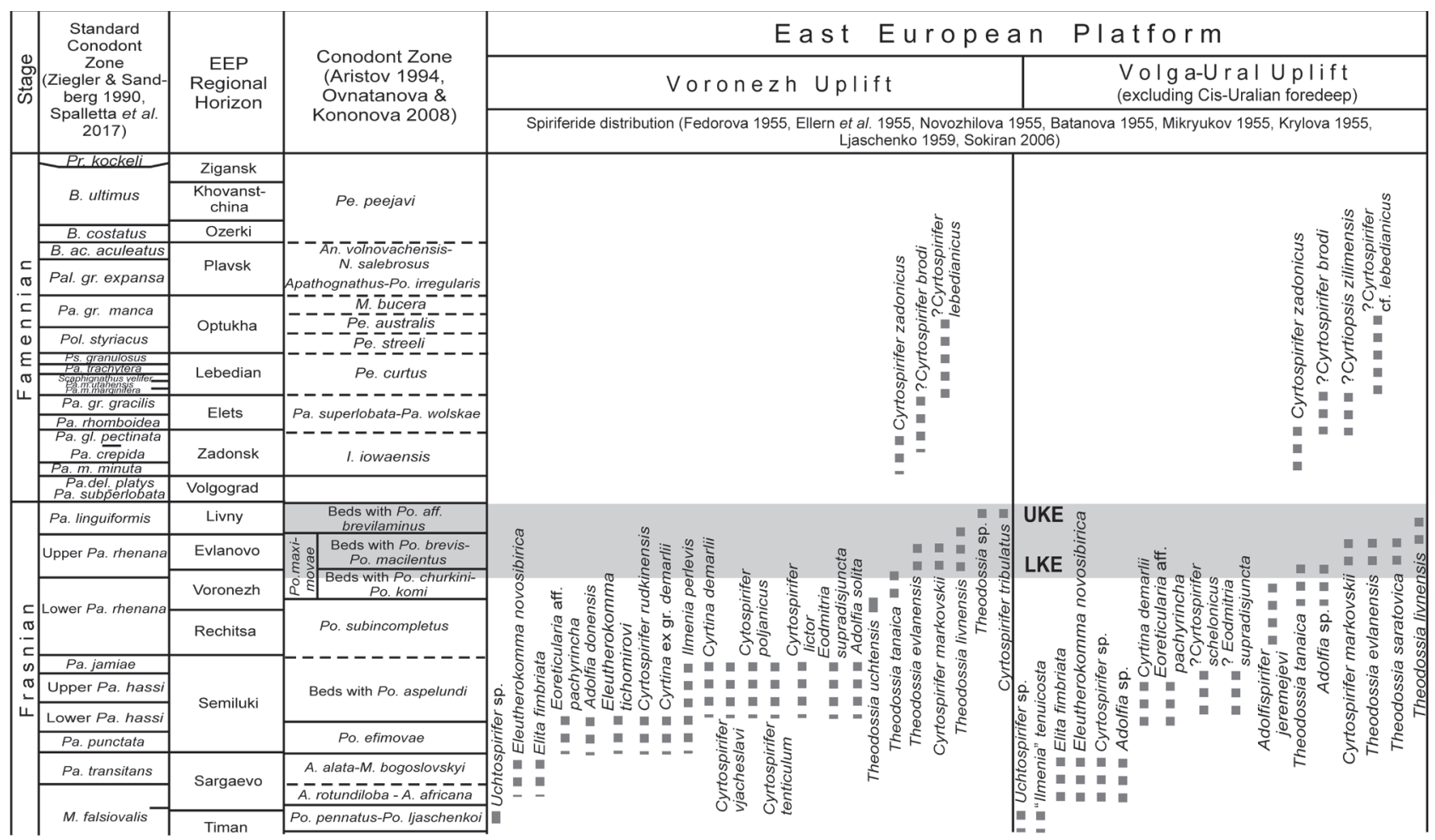

Figure 5. Distribution of spiriferid brachiopods in the F-F interval of the East European Platform. For explanations see Fig. 3.

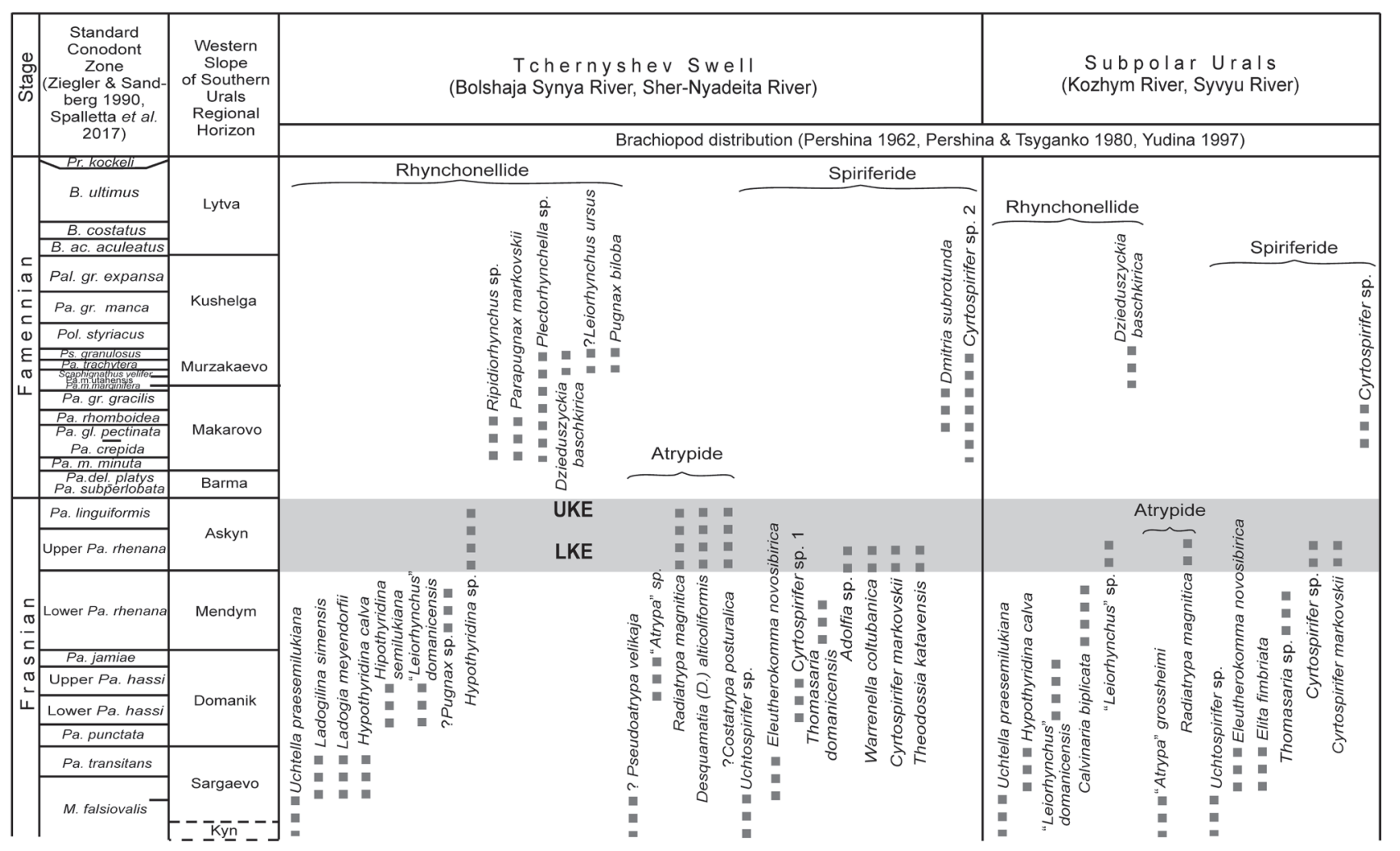

Figure 6. Brachiopod distribution in the F-F interval of the Pechora Platfrom (Tchernyshev Swell) and Urals. For explanations see Fig. 3. 


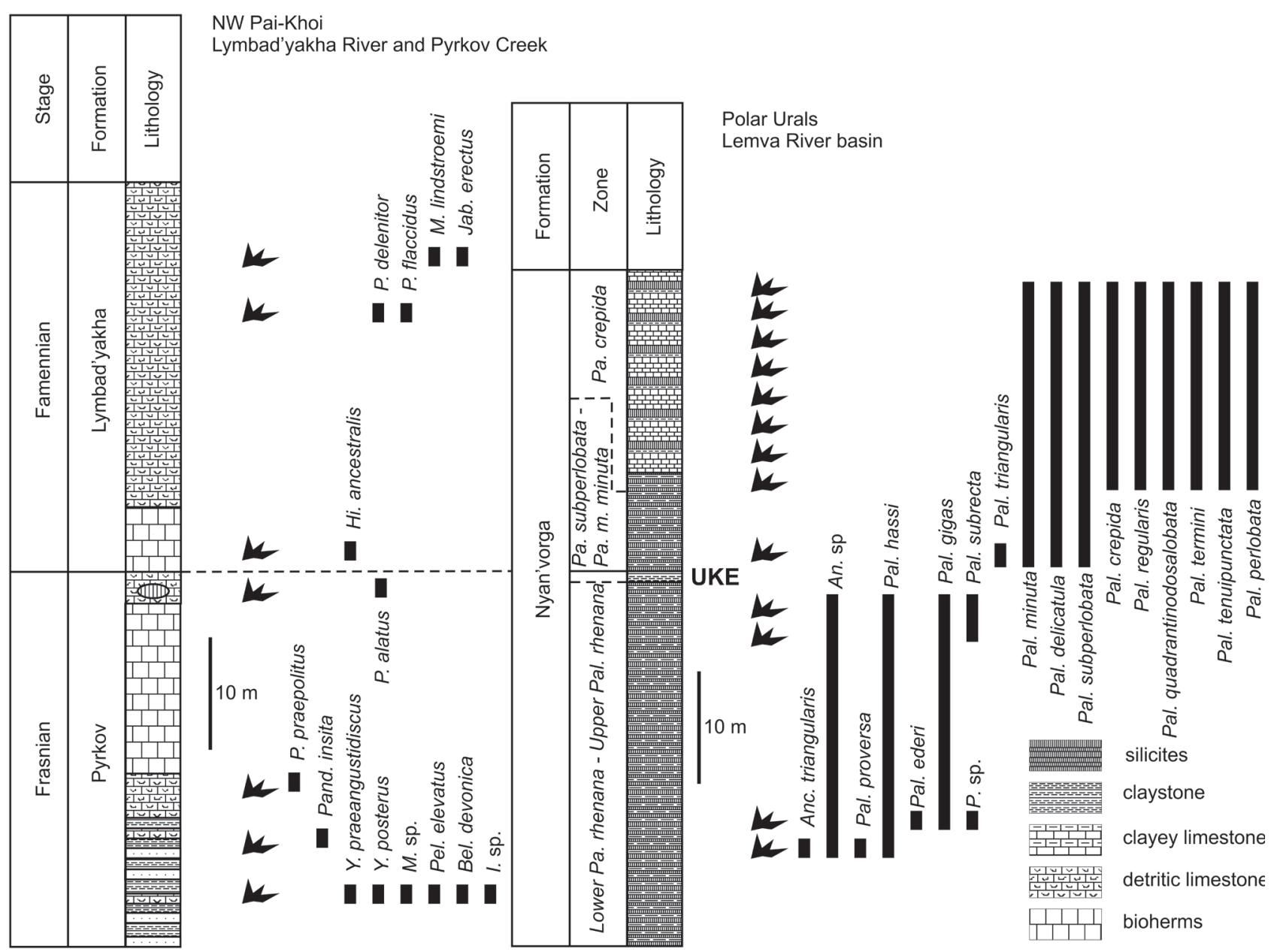

Figure 7. Lithology and conodont distribution in the F-F interval of the isolated carbonate platform (Lymbad'yakha River and Pyrkov Creek) and bathyal (Lemva River basin) sequences of the Pai-Khoi and Polar Urals (based on Zhuravlev et al. 2015 and Ovnatanova et al. 2017). Abbreviations: Anc. - Ancyrognathus, An. - Ancyrodella, Bel. - Belodella, Hi. - Hindeodus, Jab. - Jablonnodus, Pand. - Pandorinellina, Pel. - Pelekysgnathus, Y. Youngquistognathus. For other explanations see Fig. 2.

Kononova 2008) (Appendix 1). It is notable that oxygendeficient deep-water deposits span the wide stratigraphic interval that contains the upper Frasnian and the lower Famennian in this region.

\section{Pechora Platform}

Shallow-water shelf environment. - Boreholes of the north-western part of the Pechora Platform demonstrate similar successions in the F-F boundary interval. According to the data of Deulin (2006) the uppermost Frasnian, corresponding to Upper Pal. rhenana conodont Zone, is represented by bioclastic limestones containing glauconite and thin clay layers. Conodonts within these limestones consist of diverse polygnathids. The upper Frasnian limestones are overlain by dark-grey clays and clayey limestones containing early Famennian conodonts (Appendix 1).
Upper Devonian shallow-water deposits are exposed in the Tchernyshev Swell (eastern part of the Pechora Platform) as well (Tsyganko 2011). Late Devonian brachiopod faunas are known from Sher-Nadeyta River and Bolshaya Synya River sections (Fig. 6). Latest Frasnian brachiopods compose diverse associations (Appendix 2). Early Famennian brachiopods demonstrate less diversity (Pershina 1962).

\section{North of Urals}

Deep-water shelf environment. - A well-studied F-F transition section from the deep-water facies is represented by the Syvyu River section located in the Subpolar Urals (Yudina et al. 2002). The late Frasnian interval is composed of thin alternation of the dark-grey clayey limestones and limey siliceous shales, containing sponge 
spicules, radiolarians, and scarce thin-shelled brachiopods. This interval is rich in conodonts represented by various palmatolepids (Appendix 1). The lowermost Famennian is similar in lithology and is composed of alternation of grey clayey limestones and limey siliceous shales, containing sponge spicules, radiolarians, thin-shelled brachiopods, and conodonts (Appendix 1). A black shale unit corresponds to the Upper Kellwasser Event (Yudina et al. 2002). The event is represented by the disappearance of most palmatolepids and polygnathids with the appearance of numerous and diverse representatives of the genus Icriodus and some palmatolepids (Yudina et al. 2002, Soboleva et al. 2018).

Isolated platform environment. - The F-F transition in the isolated carbonate platform facies was studied in the Northern Pai-Khoy Lymbad'yakha River section (Zhuravlev et al. 2015, Zhuravlev 2016) (Fig. 7). The uppermost Frasnian in the section is represented by cherty micritic limestones overlying the microbial and algal bioherms of the Pyrkov Formation. The limestone contains rare conodonts belonging to Polygnathus alatus Huddle. The lower Famennian disconformably overlies the Frasnian limestone that probably corresponds to the earliest Famennian regression. The successive early Famennian transgression is marked by microbial-stromatoporoid bioherms of the lowermost part of the Lymbad'yakha Formation, containing only Hindeodus ancestralis (Dzik) in bioherms, and more diverse association (six taxa) in the overlying bioclastic limestones (Appendix 1). The F-F boundary interval is characterized by interruption in development of the microbial bioherms accompanied by partial erosion of the terminal Frasnian and the lowermost Famennian.

Bathyal environment. - Deep-water bathyal sequences of the F-F transition are represented by successions of the Kharuta River basin, Polar Urals (Ovnatanova et al. 2017) (Fig. 7). The terminal Frasnian is composed here by carbonaceous cherty black shales that are barren of conodonts. The overlying lowermost Famennian, containing conodonts of the Pal. subperlobata-Pal. minuta minuta zones, is composed of greenish-grey clayey cherts and cherty shales (Ovnatanova et al. 2017). Black shale (carbonaceous cherty shales) sedimentation probably corresponds to the Kellwasser Event.

\section{Siberia}

\section{Northern Siberia}

Deep-water shelf environment. - The F-F transition in the northern Siberia region is well studied in the basin facies only. The representative sections are located in the Taimyr Peninsula (Domba River section, Yolkin et al. 2006) and in the Lena River mouth (Stolb section, Yazikov et al. 2013) (Fig. 8).

The F-F interval in the Domba River section $\left(73.435100^{\circ} \mathrm{N}, 82.455725^{\circ} \mathrm{E}\right)$ contains alternating grey shales and dark-grey micritic limestones with radiolarians. Shales contain lime concretions that yielded entomozoids, bivalves, and small brachiopod shells. The limestones contain earliest Famennian conodonts of Pal. subperlobata-Pal. glabra pectinata zones (Yolkin et al. 2006) (Appendix 1).

The Lena River section $\left(71.953671^{\circ} \mathrm{N}, 127.159098^{\circ} \mathrm{E}\right)$ represents a basinal facies with clayey-carbonate sedimentation and increased palaeoseismicity (Yazikov et al. 2013). The F-F boundary beds contain mixed carbonatevolcaniclastic deposits (Fig. 8). The terminal Frasnian and lowermost Famennian deposits yield numerous brachiopods (Krylova 1959, 1962; Yazikov et al. 2013) (Appendix 2).

Latest Frasnian conodonts are unknown in this succession, but the early Famennian conodonts are represented by palmatolepids and icriodontids (Yazikov et al. 2013) (Appendix 1). A layer of black carbonaceous shales $70-\mathrm{cm}$-thick is considered as mark of UKE (Fig. 8).

\section{North-eastern Siberia}

Shallow-water shelf environment. - The FrasnianFamennian transition in the shallow-water open shelf facies is known in the western part of Kolyma Uplift, Yasachnaya Rives basin section $\left(64.507694^{\circ} \mathrm{N}, 151.230489^{\circ} \mathrm{E}\right)$ (Gagiev 2009) (Fig. 8). The upper Frasnian in this section is represented by clayey limestones with claystone and siltstone layers grading to clayey micritic laminated limestones. The deposits yield shallow-water conodonts marking Lower Pal. rhenana-Pal. linguiformis conodont zones (Appendix 1). Brachiopods were mentioned from the terminal Frasnian in the Yasachnaya and Eastern Khandyga Rivers sections, as well (Alekseeva 1967, Alekseeva et al. 1996) (Appendix 2).

The unit of clayey micritic laminated limestones in the upper part of this interval probably corresponds to the latest Frasnian (UKE) transgression. Overlaying alternation of lime sandstones and claystones (5-m-thick), grading into alternating siliceous claystones and siltstones, corresponds to the earliest Famennian regression. These deposits contain numerous conodonts, which are characteristic of Pal. subperlobata-Pal. termini conodont zones (Appendix 1). The early Famennian brachiopods were found in the Khandyga River section (Alekseeva et al. 1996) (Appendix 2). 


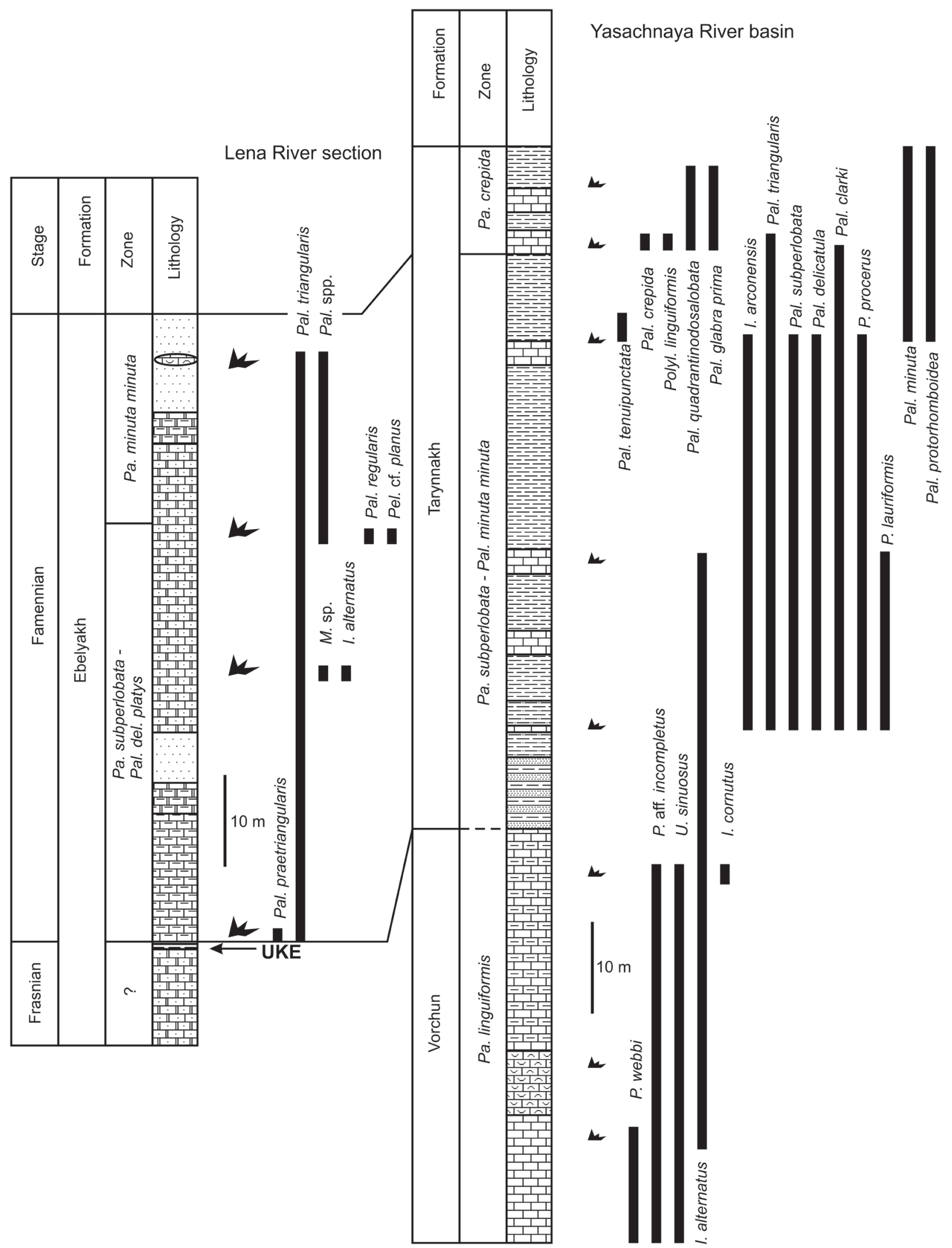

Figure 8. Lithology and conodont distribution in the F-F transition in northern Siberian sequences (based on Yazikov et al. 2013, and Gagiev, 2009). For explanations see Fig. 7. 
Deep-water shelf environment. - The deep-shelf succession of this region was reported by Gagiev (2009) in the Burgali-Kamenka section $\left(64.271122^{\circ} \mathrm{N}\right.$, $153.660630^{\circ}$ E) (eastern part of the Kolyma Uplift). The terminal Frasnian in this section contains alternating sandstones and dark-grey shales with conodonts of the Pal. linguiformis conodont Zone (Appendix 1). The lowermost Famennian is represented by dark-grey limey and silty shales with lenses of fine-grained limestones containing the early Famennian conodont associations (Appendix 1). In addition, late Frasnian-middle Famennian ( $\mathrm{Pal}$. linguiformis-Pal. marginifera marginifera zones) tuffs and volcaniclastic deposits, as well as late Frasnian (Upper Pal. rhenana conodont Zone) local basalts in the Vorchun Fm., are known in the eastern part of the Prikolymian Uplift, NE Siberia. The Kedon Fm., composed of MiddleUpper Devonian rhyolitic and subalkaline volcanic rocks and basalt sheets, is widespread in the Omolon Uplift of NE Siberia (Gagiev 2009).

\section{Facies and biota changes at the F-F transition}

Shallow-water sequences commonly demonstrate disconformities and hiatus at the F-F boundary (Alekseev et al. 1996). Subsequent transgression caused start of the shallow-water sedimentation at the Pal. minuta minutaPal. crepida conodont zones. In case of continuous F-F sequences (e.g. Yasachnaya River section, Kolyma Uplift, Siberia) the terminal Frasnian UK transgression is marked by a unit of clayey, micritic, laminated limestones.

In the deep-water facies, including troughs on the shelf, the UKE is marked by black shale (carbonaceous cherty shales, cherts, or laminated limestones) sedimentation followed by grey clayey cherts and cherty shales intercalating with calciturbidites. Some northern Siberia sequences (e.g. Lena River section) contain volcaniclastic deposits as well, but not in the narrowed F-F interval.

\section{Conodonts}

The F-F transition demonstrates weak palaeolatitude gradient in changes of conodont associations. Slightly lower conodont diversity observed in the shelf basins of Siberia is due to poor sample coverage: there are very few papers dealing with conodonts from the North Siberian deposits of this age.

The deep-water and open shelf successions of all the regions under consideration demonstrate conodont associations composed mainly of cosmopolitan species of Palmatolepis. The shallow-water successions as a rule possess stratigraphic gaps (unconformity) comprising uppermost Frasnian (Pal. linguiformis Zone) and lower part of the Famennian (Palmatolepis subperlobata-Pal. triangularis zones). The conodont associations dominated by Polygnathus and Icriodus show a diversity decrease during the late Frasnian. The early Famennian conodonts are represented mainly by species of Icriodus, cosmopolitan species of Polygnathus (e.g. Polygnathus brevilaminus), and specific taxa characterized by their coniform elements (Mitrellataxis and Jablonnodus) (Fig. 9).

Globally the gradual decrease in conodont diversity occurred during the Late Pal. rhenana-Pal. triangularis interval (Ziegler \& Lane 1987, Schülke 1998). The Frasnian conodont taxa, including Ancyrodella, most species of Palmatolepis, Polygnathus, Icriodus, and Ancyrognathus, became extinct. The dramatic decrease in conodont diversity occurred in the Pal. linguiformis conodont Zone when about $50 \%$ of conodont species disappeared and at the start of the Pal. subperlobata conodont Zone when about $70 \%$ of conodont species became extinct (Ziegler \& Lane 1987). The early Famennian recovery of conodont diversity began at the Pal. delicatula platys conodont Zone preceding the radiative phase in the Pal. minuta minuta conodont Zone (Ziegler \& Lane 1987).

The recovering conodont communities in the Famennian shallow-water facies are very specific and partly endemic. Icriodontids of Icriodus iowaensis group, Mitrellataxis, and Jablonnodus dominate the unique associations. It is notable that the recovery faunas demonstrate extremely wide ranges of $\delta^{13} \mathrm{C}_{\text {org }}$ in conodont elements of Icriodus (from $-27.9 \%$ to $-23.1 \%$ ), Mitrellataxis (from $-27.9 \%$ to $-23.6 \%$ ), and Jablonnodus (from $-28.1 \%$ to $-23.1 \%$ ). The high variability of carbon isotope composition in conodont organic matter suggests unstable trophic relations in the post-crisis shallow-water ecosystems, probably due to rapid expansion of survivors into vacant ecospace (see also Sandberg et al. 1988, Racki et al. 2002, Zhuravlev $\&$ Smoleva 2018). Appearance of icriodontids in deepwater associations seems to be the result of their postcrisis ecological expansion into the niches of eliminated taxa (biofacies telescoping of Sandberg et al. 1988, compare Huang et al. 2018), or transport of the shallowwater conodont elements to deep-water environment by intensive calciturbidite currents in the early Famennian eustatic lowstand.

\section{Brachiopods}

Late Devonian strata of northern Laurussia are characterized by taxonomically diverse and abundant brachiopods, in contrast to the mid-latitude sequences of Siberia, which contain few brachiopods (West Siberia, northern Siberia, north-eastern Siberia) or do not contain them at all (east 

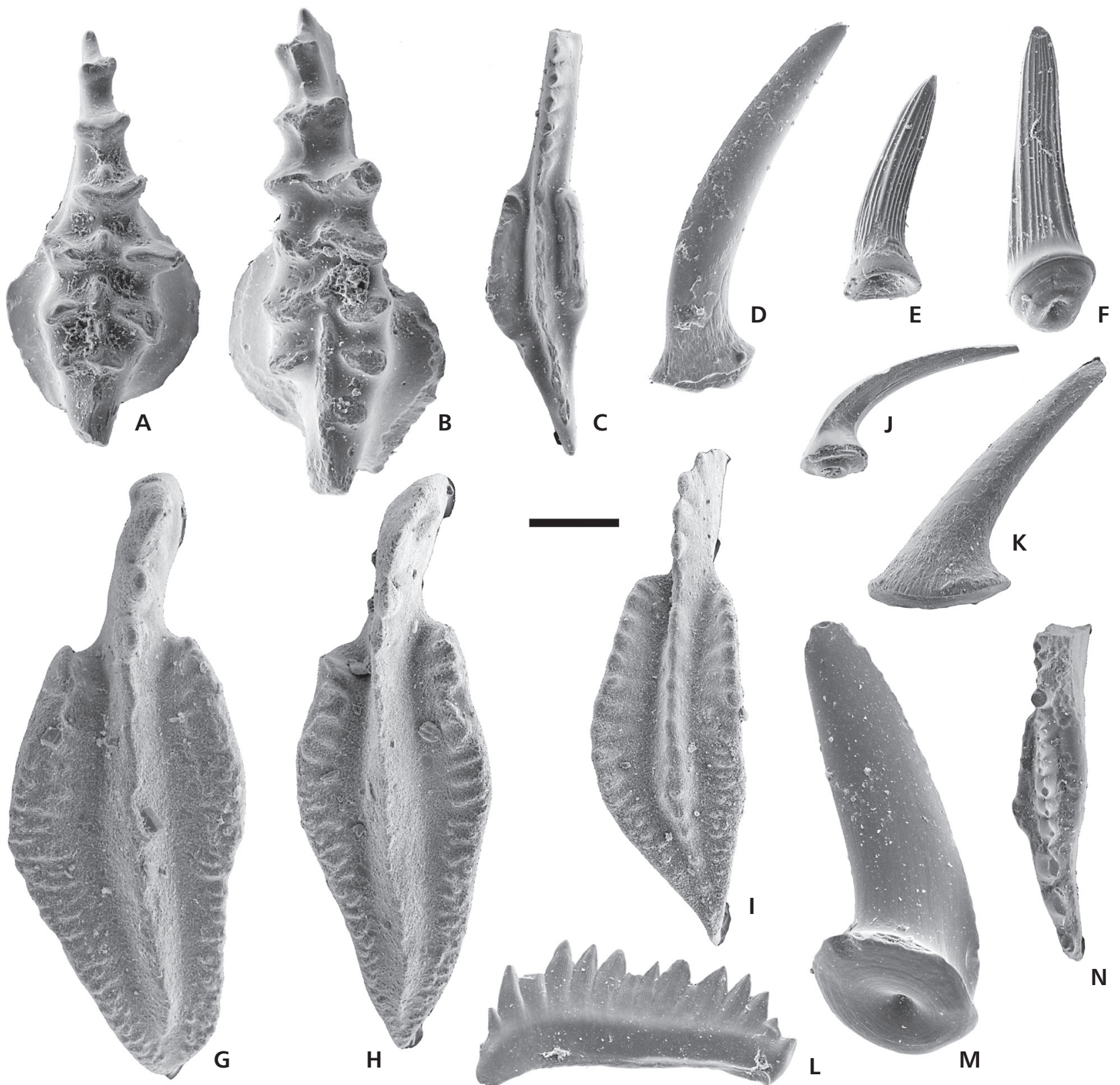

C
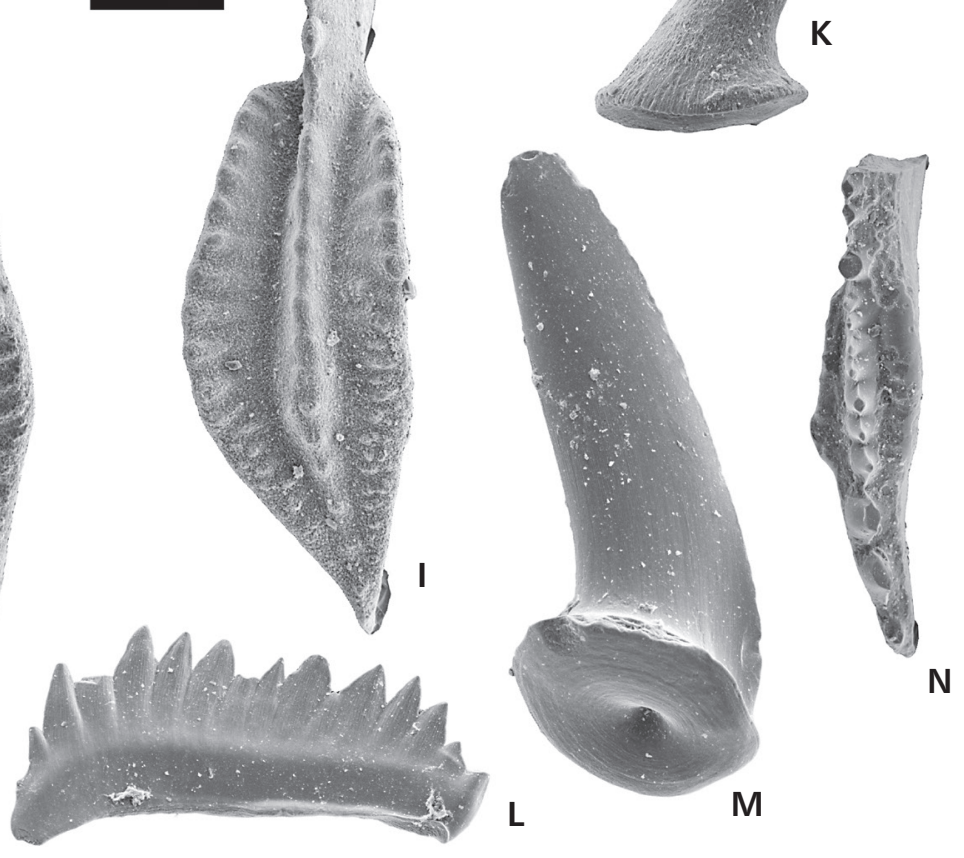

Figure 9. Characteristic conodonts from the F-F transition interval of the Voronezh Uplift, East European Platform. • A - Icriodus iowaensis iowaensis Youngquist et Peterson 1947, specimen 713/1, Zadonsk Fm., lower Famennian, Kamenka Quarry. • B - Icrodus iowaensis ancylus Sandberg et Dreesen 1984, specimen 713/2, Zadonsk Fm., lower Famennian, Kamenka Quarry. • C, N - Polygnathus brevilaminus Branson et Mehl, Zadonsk Fm., lower Famennian, Kamenka Quarry; C-specimen 713/3; N-specimen 713/23. D - Jablonnodus erectus Dzik 2006, specimen 713/7, Zadonsk Fm., lower Famennian, Russkiy Brod Quarry. • E, F - Mitrellataxis conoidalis Dzik 2006, Zadonsk Fm., lower Famennian, Russkiy Brod Quarry; E - specimen 713/8; F - specimen 713/10. • G, H - Polygnathus colliculosus Aristov 1985, Livny Fm., upper Frasnian, Kamenka Quarry; G - specimen 713/20; H - specimen 713/17. • I - Polygnathus reitlingerae Ovnatanova et Kononova 2008, specimen 713/19, Livny Fm., upper Frasnian, Kamenka Quarry. J - Jablonnodus oistodiformis Dzik 2006, specimen 713/16, Livny Fm., upper Frasnian, Kamenka Quarry. $・$ K, M - Mitrellataxis circularis (Wang et Wang 1978), Zadonsk Fm., lower Famennian; K - specimen 713/21, Kamenka Quarry; M - specimen 713/11, Russkiy Brod Quarry. $・$ L - Mehlina kielcensis Dzik 2006, specimen 713/13, Zadonsk Fm., lower Famennian, Russkiy Brod Quarry. Scale bar is $0.2 \mathrm{~mm}$.

of the Altai-Sayan region). Therefore, the Late Devonian deposits of western Siberia (Kuznetsk Basin), with the most complete of brachiopod successions (Fig. 10), are important for the analysis of the brachiopod turnover during the $\mathrm{F}-\mathrm{F}$ crisis interval in the northern midlatitudes. These brachiopod faunas were studied in detail (Rzhonsnitskaya 1968, 1975; Rzhonsnitskaya et al. 1998; Modzalevskaya et al. 2013). 


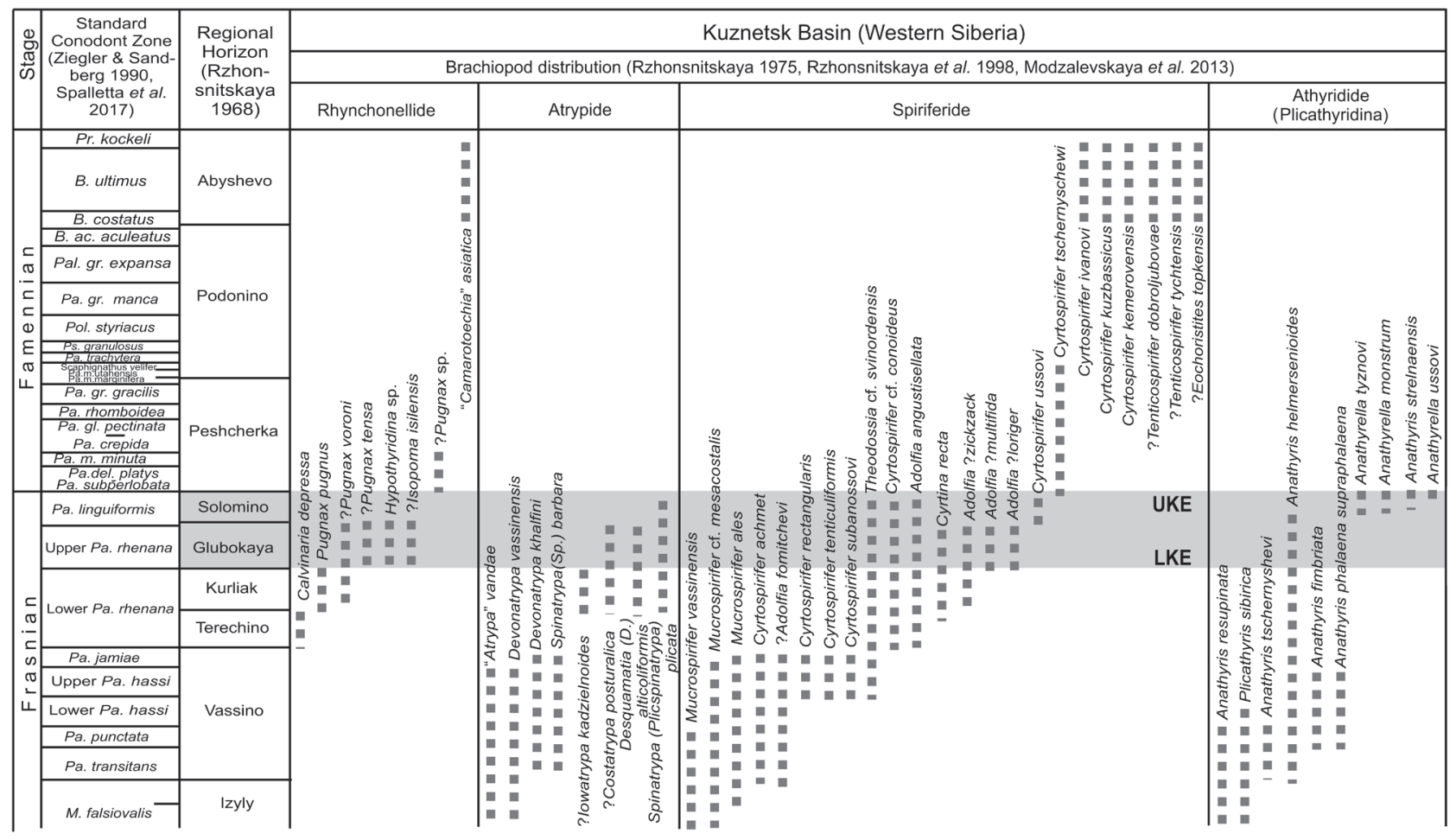

Figure 10. Brachiopod distribution in the F-F interval of the Kuznetsk Basin (West Siberia). For explanations see Fig. 3.

Most informative are the late Frasnian and early Famennian brachiopod sequences of north-eastern Laurussia located in the East European Platform (EEP), Pechora Platform, and Urals. In the central regions of the EEP and Volga-Ural area the late Frasnian ( $\mathrm{Pal}$. linguiformis conodont Zone) brachiopod fauna is extremely depleted and represented by two taxa: Cyrtospirifer tribulatus and Theodossia sp. (Figs 5, 11). This situation differs significantly from the contemporary brachiopod fauna of the western slope of South Urals and the north-eastern Pechora Platform (Tchernyshev Swell) (Fig. 6). The late Frasnian brachiopod association of SW Urals is more diverse and contains 15 species of Gypidula, "Hypothyridina", "Pugnax", Desquamatia, Radiatrypa, Costatrypa, Pseudoatrypa, Spinatrypa, Iowatrypa, Theodossia, Warrenella, Cyrtospirifer, Adolfia, and Cryptonella (Abramova 1999). This association is close to those of the Tchernyshev Swell (Fig.6) (Pershina 1962). The late Frasnian Iowatrypa, Costatrypa, Radiatrypa, and Desquamatia are common in SW Ural, north-western
Pechora Platform, and West Siberia (Kuznetsk Basin) (Fig. 10), and they were reported from the shallow-water sequences of the southeastern Laurussia (South Poland, Holy Cross Mountains) (Racki \& Baliński 1998, Baliński 2002). Iowatrypa and Costatrypa are known from the Ardennes; Desquamatia, Radiatrypa, Iowatrypa, and Costatrypa were reported from China as well (Racki 1998b).

The late Frasnian brachiopod associations of northern Laurussia (EEP, Pechora Platform, Urals, and Novaya Zemlya) and Siberia contain cyrtospiriferids and theodossiids. In the EEP and Novaya Zemlya species of Theodossia occur in almost the entire middle and late Frasnian interval (Pal.punctata-Pal. linguiformis conodont zones) (Nalivkin 1947, Rzhonsnitskaya 1988, Bezgodova 2015). In Arctic Siberia the representatives of Theodossia are distributed in the late Frasnian deposits of the Lena, Kulymbe, Kotuy, and Maimecha river basins (Krylova 1962). In contrast to the cosmopolitan Cyrtospirifer, the distinctive Theodossia was limited to northern Laurussia

Figure 11. Characteristic brachiopods from the F-F transition interval of the Voronezh Uplift, East European Platform (Russkiy Brod Quarry). A, F - Cyrtospirifer zadonicus Ljaschenko 1959, Zadonsk Fm., lower Famennian; A - specimen 713/25; F - specimen 713/31. • B - Ripidiorhynchus huotinus (Verneuil 1845), specimen 713/26, Zadonsk Fm., lower Famennian. • C, I - Donalosia multispinosa (Sokolskaja 1948), Zadonsk Fm., lower Famennian; C - specimen 713/27; I - specimen 713/34. • D, G - Theodossia sp., Zadonsk Fm., lower Famennian; D - specimen 713/28, [a-Ripidiorhynchus huotinus (Verneuil 1845), specimen 713/29], [b - Cyrtospirifer zadonicus Ljaschenko 1959, specimen 713/30]; G - specimen 713/32. • H - Cyrtospirifer tribulatus Ljaschenko1959, specimen 713/33, Livny Fm., upper Frasnian. Scale bar is $5 \mathrm{~mm}$. 

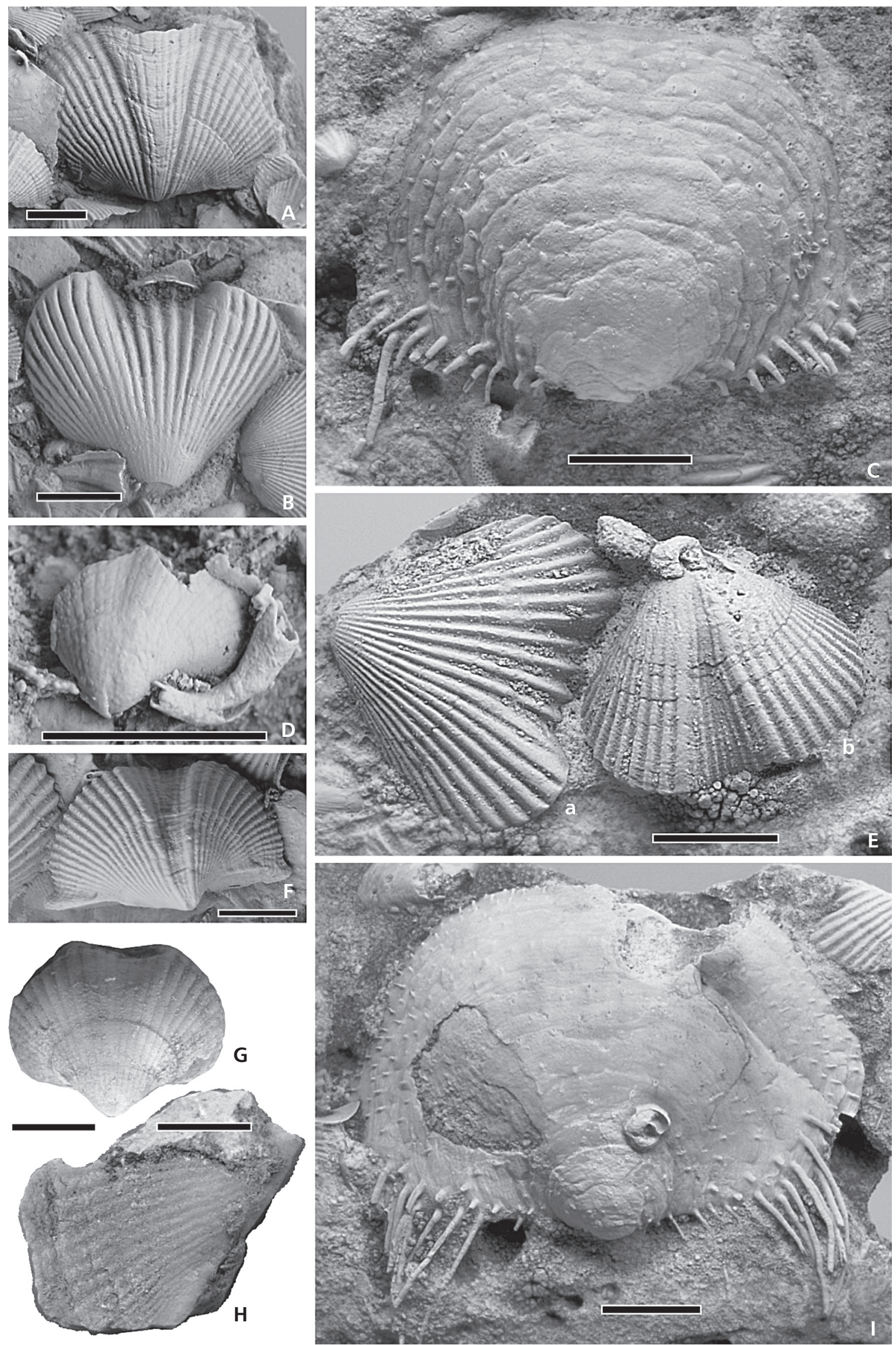
and Siberia. The late Frasnian Theodossia from South Poland (Baliński 2002) and South China (Ma et al. 2006) needs revision, as well as "Theodossia" hungerfordi from the Lime Creek Formation (Iowa, North America). However, true Theodossia probably occur in the late Frasnian of western Canada (southwestern Laurussia) (McLaren et al. 1962).

The Frasnian brachiopod faunas of western Siberia (Kuznetsk Basin) contain diverse and abundant plicathyridines; the endemic species of Anathyrella are typical for the late Frasnian sequences of this area only (Fig. 10). Nowhere else in the basins of the northern and southern hemispheres are plicathyridines recorded in the terminal Frasnian, but rather in the lower and middle Frasnian (Mottequin et al. 2016).

The late Frasnian sequences of the eastern Pechora Platform and South Urals contain Warrenella, which are also known from the South Poland, Belgium, and North America. The globally distributed (South Poland, France, Australia, New Mexico) epiplanktonic chonetid Retichonetes armata was found in the terminal Frasnian of the Stolb Island section (Lena River, Arctic Siberia) (Yazikov et al. 2013).

The early Famennian brachiopod faunas of the EEP are poorly developed. In the Central region of the EEP and Volga-Ural areas, the early Famennian deposits contain nine species of Schuchertella, Plicochonetes, Chonopectus, Donalosia, Productella, Paromoeopygma, Ripidiorhynchus, and Cyrtospirifer (see Ljaschenko 1959, Appendix 2). According to data of Abramova (1999), the coeval brachiopod faunas from SW Ural are represented only by four species (Appendix 2). The concurrent brachiopods from the Kuznetsk Basin (West Siberia) are represented by six species (Rzhonsnitskaya 1968) (Appendix 2).

The early Famennian sequences of northern Siberia are poorly characterized by brachiopods except at the Stolb section (Lena River). The brachiopods from this section have very poor preservation, and therefore they are difficult to be reliably identified (Appendix 2). Among them, Parapugnax markovskii is known from early Famennian strata of the SW Urals, Pai-Khoi, and northern Siberia. Cyrtospirifer tschernyschewi is widely distributed in the Arctic regions of Russia and in Kazakhstan. Thus, the late Frasnian and early Famennian brachiopod assemblages of low and middle latitudes of the northern hemisphere have numerous common elements that indicate similar habitats.

The detailed study of the oxygen and carbon isotope ratios in the Kosoy Utyos section (Kuznetsk Basin, West Siberia) shows the presence of a carbon isotopic anomaly in the early Famennian mid-latitude deposits. The higher $\delta^{13} \mathrm{C}_{\text {carb }}$ values in the Kosoy Utyos section, as compared with the equatorial sections, might be due to the lower temperatures of the depositional basin (Izokh et al. 2009). Cooling pulse may occur across the $\mathrm{F}-\mathrm{F}$ boundary interval (Copper 1998, Averbuch et al. 2003, Riquier et al. 2016, Huang et al. 2018), which led to the final extinction of the late Frasnian tropical brachiopod faunas and the emergence of taxa more resistant to the low temperature regime during the earliest Famennian. Therefore, the climatic change should have affected tropical and mid-latitude faunas in different degree, finally producing clear palaeolatitudinal gradient in diversity and taxonomical composition. Copper (1998) supposed that the main causes of the disappearance of the tropical order Atrypida at the end of the Frasnian were a cooling event and a regressive episode. Decrease in size of some shells of adult brachiopods may be a consequence of the temperature drop. The "Liliput" phenomenon among early Famennian brachiopods in south Poland was reported by Baliński \& Racki (1999). The late Frasnian small forms of Theodossia are known in the Voronezh Uplift (EEP) sequences. Modzalevskaya et al. (2013) reported small athyrididines from the early Famennian recovery interval of the Kuznetsk Basin, as well as Krylova (1959) from the F-F interval of the Stolb Island (northern Siberia). Small size of adult brachiopod forms can also be associated with poorly oxygenated environments. However, evident record of UKE anoxia is recognized in few of the abovementioned domains, such as the Stolb Island (Lena River) section (Yazikov et al. 2013).

\section{Discussion}

The bathyal sequences of the tropical realm contain poor associations of the pelagic conodont fauna in both the upper Frasnian and lower Famennian (Rodríguez-Cañero \& Martín-Algarra 2014, Ovnatanova et al. 2017). The associations comprise cosmopolitan species over the Laurussia and Siberia realms. Numerous conodonts in the deep-water deposits are known just from the calciturbidites and represent reworked, taphonomically enriched and mixed associations. Subautochtonous deepwater conodont associations known from the siliceous and shale deposits are taxonomically poor and composed of cosmopolitan palmatolepid species. Palaeolatitudinal trend in composition of the deep-water conodont associations is not clear. Generally conodonts demonstrate higher diversity in the tropical realm in both crisis and post-crisis intervals, and in shallow-water and deep-water environments (Fig. 12). The decrease in diversity of the associations at mid- latitudes may be due to lack of data on the sections of Siberia and north-eastern Eurasia. Simple statistical analysis demonstrates contingency in the conodont diversity changes at the F-F boundary in the low and middle latitudes $\left(\mathrm{Chi}^{2}=4.9014, \mathrm{p}=0.17916\right.$, degrees freedom $=3$ ). 

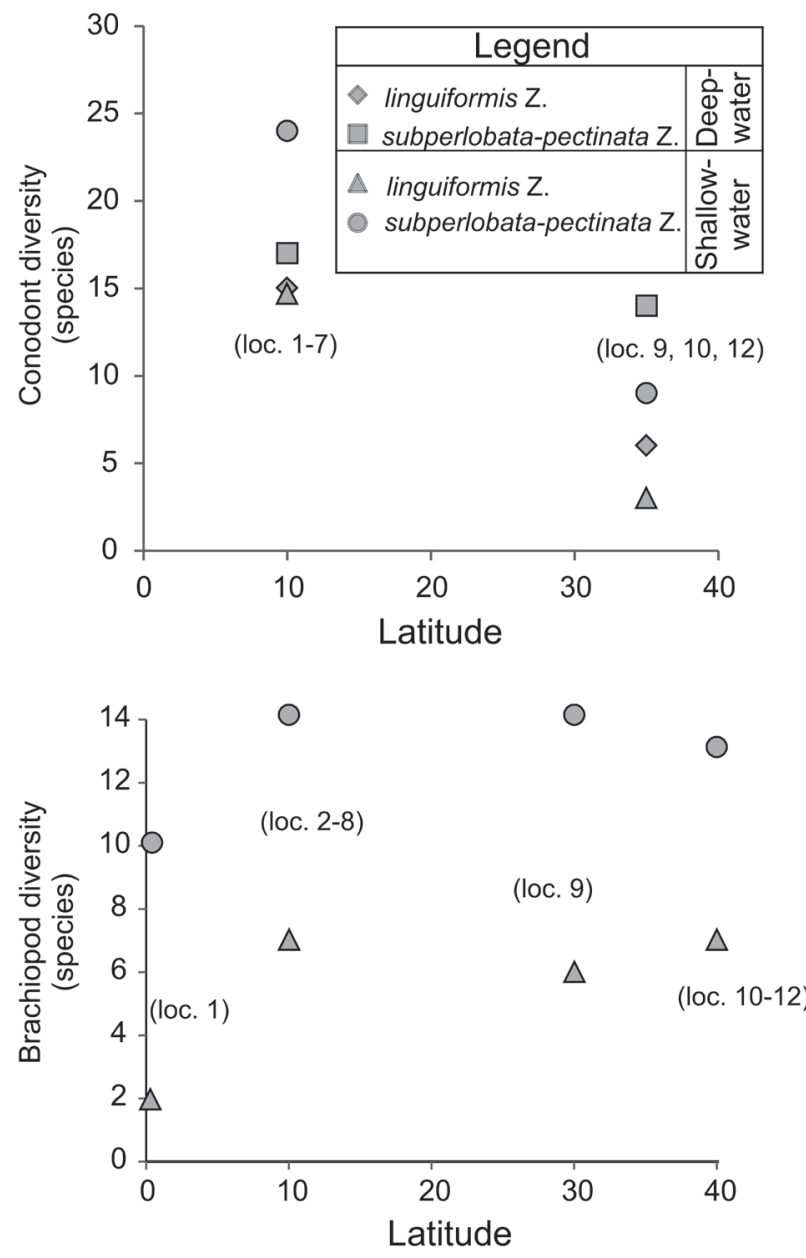

Figure 12. Conodont and brachiopod diversity in F-F boundary interval over the facies and palaeolatitudinal gradient in the northern hemisphere (NE Laurussia and Siberia). Numbers in parentheses refer to localities in Fig. 1.

Low and middle latitude brachiopods in the northern hemisphere demonstrated a generally similar evolutionary trend during the late Frasnian and early Famennian. Significant taxonomic reduction of the brachiopod associations occurred in the KW Crisis mainly due to a decrease in speciation rates, not elevated extinction rates (Stigall 2010). The earliest Famennian (recovery) associations were of low diversity and consisted of Productida, Rhynchonellida, and Spiriferida, similar to those of the southern hemisphere (Baliński \& Racki 1999). Approximately the same taxonomic framework is characteristic of the early Famennian of central Hunan (Ma et al. 2002). It seems that cyrtospiriferids and rhynchonellids, such as late Frasnian and early Famennian representatives of Ripidiorhynchus from the EEP (Sokiran 2002), were invasive taxa characterized by broad environmental tolerance (see also Stigall 2012, 2013). In South Polish carbonate shelf, persistent competition from expansive productid-cyrtospirifrid-athyrid associations is highlighted by Racki (1998b). It is notable that shelly benthos shows a low latitudinal selectivity in F-F extinction and recovery (Fig. 12) that suggests low influence of the climatic changes on the extinction pattern (Reddin et al. 2019).

Thus both the brachiopods (benthos) and conodonts (nekton) demonstrate weak or absence of obvious palaeolatitudinal gradient in F-F extinction and recovery in the northern hemisphere. This suggests low influence of the fluctuations in climate and regional circulation pattern on the fauna diversity changes at the F-F boundary interval. This conclusion is supported by data on the Late Devonian marine phytoplankton. The phytoplankton demonstrates high similarity over the "Boreal Realm" comprising eastern Laurussia and Siberia (Shen et al. 2018).

Eustatic fluctuations, which were regionally disturbed by tectonics (Hallam \& Wignall 1999), cannot be considered as a global trigger of the biotic changes. In general perspective, it seems that the latest Frasnian decrease in fauna diversity in the Siberian and northeastern Laurussia realms was caused by environment changes triggered by volcanic eruptions in the Vilyui LIP, associated with palaeorift system (Kiselev et al. 2006). Other East European LIPs and diverse volcanism recorded in successions of the Omolon Uplift (Gagiev 2009, Kravchiński 2012) should also be noted. The paroxysmal effusive activity promoted climate destabilization, and ultimately led to turnover in global oceanic circulation towards stagnation and anoxia (Ernst \& Youbi 2017, Racki et al. 2018). On the other hand, overall correspondence of carbonate facies setting and benthic/nektonic biota of the both studied continents is a noteworthy implication from this study. Thus, the assumed cataclysmic impact of large-scale flood basalt and kimberlite eruptions is difficult to recognize in litho- and biofacies specificity in the regional scale, even if supported by presence of the carbonate-volcaniclastic deposits in the most proximal Lena River section (Yazikov et al. 2013) as well as carbonate-siliciclastic and volcaniclastic deposits with gypsum evaporates of the Vilyuchan Formation in the Viluy Depression (Rusetskaya \& Belenitskaya 1990).

\section{Conclusions}

(1) Generally conodonts demonstrate higher diversity in the tropical realm in both KW Crisis and post-crisis intervals, both in shallow-water and deep-water habitats, paired with contingency in the diversity changes at the F-F boundary over the low to middle latitudes of the northern hemisphere. Palaeolatitudinal trend in composition of the conodont associations is also not very clear. 
(2) Coeval brachiopod faunas of low and middle latitudes have numerous common elements. They show low latitudinal selectivity in F-F extinction and recovery, that suggests surprisingly moderated ecological effect in the shelly benthos of the rapid climatic shifts during the KW Crisis, with probable exception of the Lilliput effect. Cyrtospiriferids and rhynchonellids, such as Ripidiorhynchus from the EEP, were likely invasive taxa.

(3) Summarizing, high similarity of the composition and stratigraphic succession of nektonic (conodonts) and benthic (brachiopods) biota, which dwelt the low- and mid-latitude realms during the F-F biotic crisis, suggests low environment gradients in the northern hemisphere (Fig. 12). Carbonate sedimentation dominantly developed in the shallow-water basins of different latitudes, which implies low temperature and precipitation variations between $10^{\circ} \mathrm{S}$ and $40^{\circ} \mathrm{N}$. The biotic and facies patterns suggest that global causes of the biotic crisis were partly affected by local and regional environment changes, but surprisingly not when they were driven by so catastrophic trigger as flood basalt eruptions of the Viluy LIP.

\section{Acknowledgements}

The manuscript benefited from the kind reviews of D.J. Over and R.B. Blodgett. We gratefully acknowledge the National Science Centre - Poland (MAESTRO grant 2013/08/A/ST10/00717 to Grzegorz Racki) for funding.

\section{References}

Abramova, A.N. 1999. Frasnian stage at the Western slope of the South Urals. 55 pp. Institute of Geology, Ufa Scientific Center, Russian Academy of Sciences, Ufa. [in Russian]

Alekseev, A.S, Kononova, L.I. \& Nikishin, A.M. 1996. The Devonian and Carboniferous of the Moscow Syneclise (Russian Platform): stratigraphy and sea-level changes. Tectonophysics 268, 149-168.

DOI 10.1016/S0040-1951(96)00229-6

AleKSEEVA, R.E. 1967. Famenskie brakhiopody Severo-Vostoka SSSR, 14-20. In Ivanovskiy, A.B. \& Sokolov, B.S. (eds) Novye dannye po biostratigrafii devona i verkhnego paleozoya Sibiri. Sibirskoe otdelenie, Institut Geologii i Geofiziki, Akademiya nauk SSSR. [in Russian]

Alekseeva, R.E., Sidjachenko, A.I., Baranov, V.V., Afanasieva, G.A., Grunt, T.A., Komarov, V.N., Lazarev, S.S. \& MananKov, I.N. 1996. Atlas of Devonian Brachiopods from Northeastern Russia (Eastern Yakutia, Magadan Region). 227 pp. Nauka, Moscow. [in Russian]

Aristov, V.A. 1988. Devonskie konodonty Central'nogo Devonskogo Polâ. 120 pp. Nauka, Moscow. [in Russian]
Aristov, V.A. 1994. Devonian and Lower Carboniferous conodonts of the Eurasia: assemblages, zonal subdivision, correlation of different facies sediments. 192 pp. Russian Academy of Sciences, Geological Institute. Moscow. [in Russian]

Averbuch, O., Tribovillard, N., Devleeschouwer, X. \& Riquier, L. 2003. Evidences for an orogenic-induced global cooling at the Frasnian-Famennian boundary (ca 376 Ma BP). In EGS-AGU-EUG JoInt Assembly (ed.) Abstracts from the meeting held in Nice, France, 6-11 April 2003, abstract id. 4072.

BALIŃSKI, A. 2002. Frasnian-Famenian brachiopod extinction and recovery in Southern Poland. Acta Palaeontologica Polonica 47(2), 289-305.

BALIŃSKI, A. \& RACKI, G. 1999. Wymieranie i odradzanie się faun ramienionogowych a kryzys na granicy franfamen. Przeglad Geologiczny 47, 373-378.

Batanova, G.P. 1955. Brachiopods of the Devonian of the eastern part of the Tatar ASSR. Trudy Vsesoûznogo Neftânogo Naučno-Issledovatel'skogo Geologorazvedočnogo Instituta, Novaâ Seriâ 88, 157-195. [in Russian]

Bezgodova, D.V. 2015. A new species of Theodossia nalivkin (Brachiopoda: Spiriferida) from the Frasnian of Novaya Zemlya. Trudy Zoologičeskogo instituta RAN 319(4), 465-479. [in Russian]

Bond, D.P.G. \& Wignall, P.B. 2008. The role of sea-level change and marine anoxia in the Frasnian-Famennian (Late Devonian) mass extinction. Palaeogeography, Palaeoclimatology, Palaeoecology 263, 107-118.

DOI 10.1016/j.palaeo.2008.02.015

Bond, D.P.G., Zatoñ, M., Wignall, P.B. \& Marynowski, L. 2013. Evidence for shallow water 'Upper Kellwasser' anoxia in the Frasnian-Famennian reefs of Alberta, Canada. Lethaia 46, 355-368. DOI 10.1111/let.12014

Boucot, A.J., Chen, X. \& Scotese, C.R. 2013. Phanerozoic Paleoclimate: An Atlas of Lithologic Indicators of Climate. 478 pp. SEPM Concepts in Sedimentology and Paleontology (Print-on-Demand Version) 11. DOI 10.2110/sepmcsp.11

Carmichael, S.K., Waters, J.A., Königsof, P., Suttner, T.J. \& KIDO, E. 2019. Paleogeography and paleoenvironments of the Late Devonian Kellwasser event: A review of its sedimentological and geochemical expression, Global and Planetary Change 183, art. 102984.

DOI 10.1016/j.gloplacha.2019.102984

Carmichael, S.K., Waters, J.A., Suttner, T.S., Kido, E. \& DeReuil, A.A. 2014. A new model for the Kellwasser Anoxia Events (Late Devonian): Shallow water anoxia in an open oceanic setting in the Central Asian Orogenic belt. Palaeogeography, Palaeoclimatology, Palaeoecology 399, 394-403. DOI 10.1016/j.palaeo.2014.02.016

Chen, D.Z. \& Tucker, M.E. 2003. The Frasnian - Famennian mass extinction: insights from high-resolution sequence stratigraphy and cyclostratigraphy in South China. Palaeogeography, Palaeoecology, Palaeoclimatology 193, 87-111. DOI 10.1016/S0031-0182(02)00716-2

Copper, P. 1998. Evaluating the Frasnian-Famennian mass extinction: Comparing brachiopod faunas. Acta Palaeontologica Polonica 43(2), 137-154. 
Crasquin, S. \& Horne, D.J. 2018. The palaeopsychrosphere in the Devonian. Lethaia 51(4), 547-563.

DOI 10.1111/let.12277

Deulin, Yu.V. 2006. Conodonts and correlation of Upper Devonian petroliferous deposits of the Northern Timan-Pechora Province. 253 pp. GIN RAN, Arkhangelsk. [in Russian]

DzIK, J. 2006. The Famennian "Golden Age" of conodonts and ammonoids in the Polish part of the Variscan sea. Palaeontologica Polonica 63, 1-360.

Ellern, S.S., Ivanov, E.E. \& Kurbanov, F.J. 1955. Brachiopods of the Devonian of the Tatar ASSR. Trudy Vsesoúznogo Neftânogo Naučno-Issledovatel'skogo Geologorazvedočnogo Instituta, Novaâ Seriâ 88, 107-145. [in Russian]

ERnst, R.E. \& YoubI, N. 2017. How Large Igneous Provinces affect global climate, sometimes cause mass extinctions, and represent natural markers in the geological record. Palaeogeography, Palaeoecology, Palaeoclimatology 478, 30-52. DOI 10.1016/j.palaeo.2017.03.014

Fedorova, T.I. 1955. Brachiopods of the Devonian sediments of the Saratov region. Trudy Vsesoûznogo Neftânogo NaučnoIssledovatel'skogo Geologorazvedočnogo Instituta, Novâ̂ Seriâ 88, 7-47. [in Russian]

Gagiev, M.H. 2009. Stratigraphy of Devonian and Lower Carboniferous of the Prikolymian Uplift (Northeastern Asia). 290 pp. NEISRI FEB RAS, Magadan. [in Russian, English abstract]

Gereke, M. \& Schindler, E. 2012. "Time-Specific Facies" and biological crises - The Kellwasser Event interval near the Frasnian/Famennian boundary (Late Devonian). Palaeogeography, Palaeoclimatology, Palaeoecology 367368, 19-29. DOI 10.1016/j.palaeo.2011.11.024

Gholamalian, H. 2007. Conodont biostratigraphy of the FrasnianFamennian boundary in the Esfahan and Tabas areas, Central Iran. Geological Quarterly 51(4), 453-476.

Hallam, A. \& Wignall, P.B. 1999. Mass extinctions and sealevel changes. Earth-Science Reviews 48(4), 217-250. DOI 10.1016/S0012-8252(99)00055-0

HLADIL, J. 2002. Geophysical records of dispersed weathering products on the Frasnian carbonate platform and early Famennian ramps in Moravia, Czech Republic: proxies for eustasy and palaeoclimate. Palaeogeography, Palaeoclimatology, Palaeoecology 181(1-3), 213-250.

DOI 10.1016/S0031-0182(01)00480-1

Huang, C., Joachimski, M.M. \& Gong, Y. 2018. Did climate changes trigger the Late Devonian Kellwasser Crisis? Evidence from a high-resolution conodont $\delta^{18} \mathrm{O}_{\mathrm{PO} 4}$ record from South China. Earth and Planetary Science Letters 495, 174-184. DOI 10.1016/j.eps1.2018.05.016

Izokn, O.P., Izokh, N.G., Ponomarchuk, V.A. \& Semenova, D.V. 2009. Carbon and oxygen isotopes in the Frasnian-Famennian section of the Kuznetsk Basin (southern West Siberia). Geologiya i Geofizika (Russian Geology and Geophysics) 50(7), 786-795. DOI 10.1016/j.rgg.2008.12.007

Joachimski, M.M., Ostertag-Henning, C., Pancost, R.D., Strauss, H., Freeman, K.H., Littke, R., Sinninghe Damsté, J.S. \& RACKi, G. 2001. Water column anoxia, enhanced productivity and concomitant changes in $\delta^{13} \mathrm{C}$ and $\delta^{34} \mathrm{~S}$ across the Frasnian-Famennian boundary (Kowala - Holy Cross Mountains/Poland). Chemical Geology 175, 109-131.

DOI 10.1016/S0009-2541(00)00365-X

Kiselev, A.I., Yarmolyuk, V.V., Egorov, K.N., Chernyshov, R.A. \& Nikiforov, A.V. 2006. Middle Paleozoic Basic Magmatism of the Northwestern Vilyui Rift: Composition, Sources, and Geodynamics. Petrology 14(6), 588-608. DOI 10.1134/S0869591106060051

KRAVChí́sky, V.A. 2012. Paleozoic large igneous provinces of northern Eurasia: Correlation with mass extinction events. Global and Planetary Change 86-87, 31-36.

DOI 10.1016/j.gloplacha.2012.01.007

Krawczyński, W., Piechota, A., Sobstel, M., Sokiran, E. \& FILIPIAK, P. 2004. Faunistyczne i środowiskowe zmiany na granicy fran-famen w profilu geologicznym Kamenki (Centralne Pole Dewońskie, Rosja), p. 38. In XIX Konferencja Paleobiologów i Biostratygrafów PTG, Wrocław 16-18.09. 2004.

Krylova, A.K. 1955. Spiriferids of the Devonian of the Volga-Ural region. Trudy Vsesoûznogo Neftânogo NaučnoIssledovatel'skogo Geologorazvedočnogo Instituta, Novaâ Seriâ 88, 297-331. [in Russian]

Krylova, A.K. 1959. The Upper Devonian of Stolb Island in the Lena River mouth. Doklady AN SSSR 124(1), 162-164. [in Russian]

Krylova, A.K. 1962. Stratigrafia i brachiopody devona Sibirskoy platformy [Stratigraphy and brachiopods of the Devonian of Siberian Platform]. 108pp. Tr. VNIGRI, 200. Gostoptekhizdat, Leningrad. [in Russian]

LAsh, G.G. 2017. A multiproxy analysis of the FrasnianFamennian transition in western New York State, U.S.A. Palaeogeography, Palaeoclimatology, Palaeoecology 473, 108-122. DOI 10.1016/j.palaeo.2017.02.032

LJASCHENKO, A.I. 1959. Atlas brahiopod i stratigrafiâ devonskih otloženij centralnyh oblastej Russkoj Platformy. $451 \mathrm{pp}$. Gostoptehizdat, Moskva. [in Russian]

MA, X.P., Becker, R.T., Li, H., \& Sun, Y.Y. 2006. Early and Middle Frasnian brachiopod faunas and turnover on the South China shelf. Acta Palaeontologica Polonica 51(4), 789-812.

Ma, X.P., Gong, Y., Chen, D., Racki, G., Chen, X., \& Liao, W.H. 2016. The Late Devonian Frasnian-Famennian event in South China - Patterns and causes of extinctions, sea level changes, and isotope variations. Palaeogeography, Palaeoclimatology, Palaeoecology 448, 224-244.

DOI 10.1016/j.palaeo.2015.10.047

MA, X.P., Sun, Y.L., HAO, W.C., \& LiaO, W.H. 2002. Rugose corals and brachiopods across the Frasnian - Famennian boundary in central Hunan, South China. Acta Palaeontologica Polonica 47(2), 373-396.

McGhee, G.R. 2013. When the Invasion of Land Failed. The Legacy of the Devonian Extinctions. 336 pp. Columbia University Press, New York. DOI 10.7312/columbia/9780231160575.001.0001

McLaren, D.J., Norris, A.W. \& Mcgregor, D.C. 1962. Illustrations of Canadian fossils, Devonian of western Canada. Geological Survey of Canada, Department of Mines and Technical Surveys, paper 62-4, 35 pp. DOI 10.4095/101136 
Mikryukov, M.F. 1955. Devonian brachiopods of Western Bashkiria. Trudy Vsesoûznogo Neftânogo Naučno-Issledovatel'skogo Geologorazvedočnogo Instituta, Novaâ Seriâ 88, 203-249. [in Russian]

Modzalevskaya, T.L., Alvarez, F. \& Rzhonsnitskaya, M.A. 2013. Evolution, migration and biogeography of the plicathyridine brachiopods with a revision of Devonian faunas from the Kuznetsk Basin, Russia. Memoirs of the Association of Australasian Palaeontologists 44, 27-52.

Mottequin, B., Brice, D., Marion, J.-M. \& Simon, E. 2016. Plicathyridine brachiopods (Athyridida) from the Frasnian (Late Devonian) of Western Europe and Middle East. Geobios 49(5), 381-393. DOI 10.1016/j.geobios.2016.06.004

Nalivkin, D.V. 1947. Class Brachiopoda, 63-134. In NaLivkin, D.V. \& Verber, V.N. (eds) Atlas rukovodâsih form iskopaemyh faun SSSR, Vol. 3, Devonskâ̂ Sistema. VSEGEIGosgeoltekhizdat, Leningrad. [in Russian]

Novozhilova, S.I. 1955. Brachiopods of the Devonian of the Kuibyshev and Chkalov Regions. Trudy Vsesoûznogo Neftânogo Naučno-Issledovatel'skogo Geologorazvedočnogo Instituta, Novaâ Seriâ 88, 61-89. [in Russian]

Ovnatanova, N.S. \& Kononova, L.I. 2008. Frasnian Conodonts from the Eastern Russian Platform. Paleontological Journal 42(10), 997-1166. DOI 10.1134/S0031030108100018

Ovnatanova, N.S., Kononova, L.I., Kolesnik, L.S. \& Gatovsky, YU.A. 2017. Upper Devonian conodonts of Northeastern European Russia. Paleontological Journal 51(10), 973-1165. DOI 10.1134/S003103011710001X

Percival, L.M.E., Davies, J.H.F.L., Schaltegger, U., De Vleeschouwer, D., Da Silva, A.-C. \& Föllmi, K.B. 2018. Precisely dating the Frasnian-Famennian boundary: implications for the cause of the Late Devonian mass extinction. Scientific Reports 8(1), art. 9578. DOI 10.1038/s41598-018-27847-7

Pershina, A.I. 1962. Silurian and Devonian deposits of the Chernyshev Swell. 122 pp. Nauka, Moscow, Leningrad. [in Russian]

Pershina, A.I. \& Tsyganko, V.S. 1980. New data on Stratigraphy of Devonian and Silurian deposits of the southeast Pai-Khoi, 3-19. In Molin, V.A. \& Tsyganko, V.S. (eds) Phanerozoic of the North of the European part of USSR. Syktyvkar. [in Russian]

Pujol, F., Berner, Z., \& StüBen, D. 2006. Palaeoenvironmental changes at the Frasnian/Famennian boundary in key European sections: Chemostratigraphic constraints. Palaeogeography, Palaeoclimatology, Palaeoecology 240, 120-145.

DOI 10.1016/j.palaeo.2006.03.055

Qie, W., Algeo, T.J., Luo, G. \& Herrmann, A. 2019. Global events of the Late Paleozoic (Early Devonian to Middle Permian): A review. Palaeogeography, Palaeoclimatology, Palaeoecology 531(A), art. 109259.

DOI 10.1016/j.palaeo.2019.109259

RACKI, G. 1998a. Frasnian-Famennian biotic crisis: Undervalued tectonic control? Palaeogeography, Palaeoclimatology, Palaeoecology 141, 177-198.

DOI 10.1016/S0031-0182(98)00059-5

RACKI, G. 1998b. The Frasnian-Famennian brachiopod extinction events: A preliminary review. Acta Palaeontologica Polonica 43(2), 395-411.

Racki, G. \& Baliński, A. 1998. Late Frasnian Atrypida (Brachiopoda) from Poland and the Frasnian-Famennian biotic crisis. Acta Palaeontologica Polonica 43(2), 273-304.

Racki, G., Racka, M., Matyja, H. \& Devleeschouwer, X. 2002. The Frasnian/Famennian boundary interval in the South Polish-Moravian shelf basins: integrated event-stratigraphical approach. Palaeogeography, Palaeoclimatology, Palaeoecology 181, 251-297. DOI 10.1016/S0031-0182(01)00481-3

Racki, G., Rakocinski, M., Marynowski, L. \& Wignall, P.B. 2018. Mercury enrichments and the Frasnian-Famennian biotic crisis: A volcanic trigger proved? Geology 46(6), 543-546. DOI 10.1130/G40233.1

Reddin, C.J., Kocsis, Á.T. \& Kiessurng, W. 2019. Climate change and the latitudinal selectivity of ancient marine extinctions. Paleobiology 45(1), 70-84. DOI 10.1017/pab.2018.34

Ricci, J., Quidelleur, X., Pavlov, V., Orlov, S., Shatsillo, A. \& Courtillot, V. 2013. New ${ }^{40} \mathrm{Ar} /{ }^{39} \mathrm{Ar}$ and $\mathrm{K}-\mathrm{Ar}$ ages of the Viluy traps (eastern Siberia): Further evidence for a relationship with the Frasnian-Famennian mass extinction. Palaeogeography, Palaeoclimatology, Palaeoecology 386, 531-540. DOI 10.1016/j.palaeo.2013.06.020

Riquier, L., Averbuch, O., Tribovillard, N., Albani, A. El, LAZReQ, N. \& ChaKIRI, S. 2016. Environmental changes at the Frasnian-Famennian boundary in Central Morocco (Northern Gondwana): integrated rock-magnetic and geochemical studies, 197-217. In Becker, R.T. \& Kirchgasser, W.T. (eds), Devonian Events and Correlations. Geological Society, London, Special Publications 278. DOI 10.1144/SP278.9

Rodríguez-Cañero, R. \& Martín-Algarra, A. 2014. FrasnianFamennian crisis in the Malaguide Complex (Betic Cordillera, Spain). Terra Nova 26(1), 38-54. DOI 10.1111/ter.12068

Rusetskaya, G.A. \& Belenitskaya, G.A. 1990. Siberian Platform, 241-253. In BelenitskayA, G.A. \& ZadorozhnayA, N.M. (eds) Riftogennye i sul'fatonosnye formatsyi fanerozoâ SSSR. Nedra, Moscow. [in Russian]

Rzhonsnitskaya, M.A. 1968. Devonian Biostratigraphy of the Outskirts of the Kuznetsk Basin. 1. Stratigraphy. 287 pp. Nedra, Leningrad. [in Russian]

Rzhonsnitskaya, M.A. 1975. Devonian Biostratigraphy of the Outskirts of the Kuznetsk Basin. 2. Brachiopod Descriptions 1, Pentamerida and Atrypida. 232 pp. Nedra, Leningrad. [in Russian]

Rzhonsnitskaya, M.A. 1988. Biostratigraphic scheme of the Devonian of the Russian Platform. Canadian Society of Petroleum Geologists, Memoir 14(3), 691-702.

Rzhonsnitskaya, M.A., Markovskit, B.P., Yudina, Y.A. \& Sokiran, E.V. 1998. Late Frasnian Atrypida (Brachiopoda) from the South Urals, South Timan and Kuznetsk Basin (Russia). Acta Palaeontologica Polonica 43(2), 305-344.

SANDBERG, C.A. \& Dreesen, R. 1984. Late Devonian icriodontid biofacies models and alternative shallow-water conodont zonation. Geological Society of America Special Paper 196, 143-178. DOI 10.1130/SPE196-p143

Sandberg, C.A., Ziegler, W., Dreesen, R. \& Butler, J.L. 1988. 
Late Frasnian Mass Extinction: Conodont Event Stratigraphy, Global Changes, and possible Causes. Courier Forschungsinstitut Senckenberg 102, 263-307.

SCHÜlKe, I. 1998. Conodont community structure around the "Kellwasser mass extinction event" (Frasnian/Famennian boundary interval). Senckenbergiana lethaea 77(1/2), 87-99. DOI 10.1007/BF03043736

Scotese, C.R. 2016. PALEOMAP PaleoAtlas for GPlates and the PaleoDataPlotter program. Geological Society of America Abstracts with Programs 48(5). DOI 10.1130/abs/2016NC-275387

Shen, Z., Song, J., Servais, T. \& Gong, Y. 2018. Late Devonian palaeobiogeography of marine organic-walled phytoplankton, Palaeogeography, Palaeoclimatology, Palaeoecology 531(A), art. 108706. DOI 10.1016/j.palaeo.2018.03.018

Soboleva, M.A., Sobolev, D.B. \& Matveeva, N.A. 2018. Razrez franskogo yarusa na r. Kozhym (zapadnyy sklon Pripolyarnogo Urala) - rezul'taty biostratigraficheskikh, bio-, litofatsial'nykh i izotopno-geokhimicheskikh issledovaniy [Frasnian section on the Kozhym River (the western slope of Polar Urals) - results of biostratigraphic, bio- and lithofacies, isotopic and geochemical studies]. Neftegazovaya Geologiya. Teoriya i Praktika 13(1), available at: http://www.ngtp.ru/ rub/2/2 2018.pdf [in Russian, English abstract] DOI 10.17353/2070-5379/2 2018

SOKIRAN, E.V. 2002. Frasnian-Famennian extinction and recovery of rhynchonellid brachiopods from the East European Platform. Acta Palaeontologica Polonica 47(2), 339-354.

SoKIRAN, E.V. 2006. Early-Middle Frasnian cyrtospiriferid brachiopods from the East European Platform. Acta Palaeontologica Polonica 51(4), 759-772.

SoKolsKaJA, A.N. 1948. Evolutsia roda Productella i smezhnykh s nim form v paleozoe Podmoskovnoy kotloviny. 168 pp. Nauka, Moscow. [in Russian]

Spalletta, C., Perri, M.C., Over, D.J. \& Corradini, C. 2017. Famennian (Upper Devonian) conodont zonation: revised global standard. Bulletin of Geosciences 92(1), 31-57. DOI 10.3140/bull.geosci.1623

Stanley, S.M. 2016. Estimates of the magnitudes of major marine mass extinctions in earth history. PNAS 113(42), E6325-E6334. DOI 10.1073/pnas.1613094113

Stigall, A.L. 2010. Invasive species and biodiversity crises: Testing the link in the Late Devonian. PLoS ONE 5(12), e15584. DOI 10.1371/journal.pone.0015584

Stigall, A.L. 2012. Speciation collapse and invasive species dynamics during the Late Devonian "Mass Extinction". GSA Today: A Publication of the Geological Society of America 22(1), 4-10. DOI 10.1130/G128A.1

Stigall, A.L. 2013. Analysing links between biogeography, niche stability and speciation: the impact of complex feedbacks on macroevolutionary patterns. Palaeontology 56(6), 1225-1238. DOI 10.1111/pala.12003

TsyganKo, V.S. 2011. Devon zapadnogo sklona severa Urala i Pai-Khoia (stratigrafiâ, printsipy raschleneniâ, korrelyatsiâ). 356 pp. UrO RAN, Ekaterinburg. [in Russian]

Verneuil, E. 1845. Geologie de la Russie d'Europe et des Montagnes de l'Oural. Paleontologie 2.512 pp. Paris.
WANG, C. \& WANG, Z. 1978. Upper Devonian and Lower Carboniferous conodonts from southern Guizhou. Memoirs of the Nanjing Institute of Geology and Palaeontology, Academia Sinica 11, 51-91.

Winter, J. 2015. Vulkanismus und Kellwasser-Krise-ZirkonTephrostratigrafie, Identifizierung und Herkunft distaler Fallout-Aschenlagen (Oberdevon, Synklinorium von Dinant, Rheinisches Schiefergebirge, Harz). Zeitschrift der Deutschen Gesellschaft für Geowissenschaften 166, 227-251.

DOI 10.1127/1860-1804/2015/0092

Yazikov, A.Yu., Izokh, N.G., Saraev, S.V., Bakharev, N.K., Gonta, T.V. \& Sobolev, E.S. 2013. New data on the Upper Devonian biostratigraphy and sedimentology of Stolb Island (Lena River delta). Russian Geology and Geophysics 54(8), 780-791. DOI 10.1016/j.rgg.2013.07.003

Yolkin, E.A., Izokh, N.G. \& Romanov, A.P. 2006. New findings of the Early Famennian conodonts from the West Taimyr. News of Paleontology and Stratigraphy 9, 31-37.

Youngquist, W. \& Peterson, R.F. 1947. Conodonts from the Sheffield Formation of north-central Iowa. Journal of Paleontology 21, 242-253.

YudinA, Y.A. 1997. Rhynchonellids (Brachiopoda) from the Barma deposits of the western slope of the South Urals. Paleontological Journal 5, 63-67. [in Russian]

Yudina, A.B., Racki, G., Savage, N.S., Racka, M., \& MąKowsKI, K. 2002. The Frasnian-Famennian events in a deepshelf succession, subpolar Urals: Biotic, depositional and geochemical records. Acta Palaeontologica Polonica 47, 355-372.

Zatoń, M., Zhuravlev, A.V., Rakociński, M., Filipiak, P., BorszcZ, T., Krawczyński, W., Wilson, M.A. \& Sokiran, E.V. 2014. Microconchid-dominated cobbles from the Upper Devonian of Russia: Opportunism and dominance in a restricted environment following the Frasnian-Famennian biotic crisis. Palaeogeography, Palaeoclimatology, Palaeoecology 401, 142-153. DOI 10.1016/j.palaeo.2014.02.029

Zhuravlev, A.V. 2008. Stratigraphic characteristic of the Upper Devonian deposits in the Kara River middle course (SW Pay-Khoy). Neftegazovaya Geologiya. Teoriya i Praktika 3(4), available at: http://www.ngtp.ru/rub/2/48_2008.pdf [in Russian, English abstract]

Zhuravlev, A.V. 2016. Stroenie i usloviya formirovaniya franskikh otlozheniy severo-zapadnogo Pai-Khoia [Structure and formation conditions of Frasnian section, northwest PaiKhoi]. Neftegazovaya Geologiya. Teoriya i Praktika 11(4), available at: http://www.ngtp.ru/rub/2/38_2016.pdf [in Russian, English abstract] DOI 10.17353/2070-5379/38_2016

Zhuravlev, A.V., Gerasimova, A.I. \& Vevel, Y.A. 2015. Mestnaya stratigraficheskaya schema verkhnedevonskosrednekamennougol'nogo interval severa Paikhoiskogo karbonatnogo paravtokhtona [Local stratigraphical map of Upper Devonian - Middle Carboniferous interval of Northern Pay Khoy carbonate parautochthone]. Vestnik IG Komi SC UrB RAS 4, 8-13. [in Russian, English abstract] DOI 10.19110/2221-1381-2016-4-24-28

Zhuravlev, A.V. \& Smoleva, I.V. 2018. Carbon isotope values in conodont elements from the latest Devonian Early Carbon- 
iferous carbonate platform facies (Timan-Pechora Basin). Estonian Journal of Earth Sciences 67(4), 238-246.

DOI 10.3176/earth.2018.17

Ziegler, W. \& Lane, H.R. 1987. Cycles in conodont evolution from Devonian to mid-Carboniferous, 147-163. In ALDRIDGE,
R.J. (ed.) Palaeobiology of conodonts. Ellis Horwood, Chichester.

Ziegler, W. \& SAndberg, C.A. 1990. The Late Devonian standard conodont zonation. Courier Forschungsinstitut Senckenberg $121,1-115$.

Appendix 1. List of conodont taxa in the late Frasnian and early Famennian.

\section{East European Platform, Voronezh Uplift (Zatoń et al. 2014; new data)}

Latest Frasnian: Polygnathus krestovnikovi Ovnatanova, P. makhlinae Kirilishina et Kononova, P. krutoensis Kirilishina et Kononova, $P$. unicornis Muller et Muller, $P$. azigomorphus Aristov, P. colliculosus Aristov, P. webbi Stauffer.

Early Famennian: Palmatolepis subperlobata Branson et Mehl, Polygnathus brevilaminus Branson et Mehl, P. aff. $P$. izhmensis Kuzmin, $P$. aspelundi Savage et Funai, $P$. subnormalis Vorontsova et Kuz'min, $P$. ex gr. P. tigrinus Kuzmin et Melnikova, P. ovatus Helms, Mehlina fitzroyi (Druce), Meh. kielcensis Dzik, Icriodus iowaensis Youngquist et Peterson, I. cornutus Sannemann, Mitrellataxis conoidalis Dzik, Mit. circularis (Wang et Wang).

\section{East European Platform, Volga-Ural Uplift (Ovnatanova \& Kononova 2008)}

Latest Frasnian: Palmatolepis foliacea Youngquist, Pal. subrecta Miller et Youngquist, Pal. nasuta Muller, Pal. juntionensis Han, Pal. praetriangularis Sandberg et Ziegler, Ancyrodella ioides Ziegler, Polygnathus brevis Miller et Youngquist.

Early Famennian: Palmatolepis subperlobata Branson et Mehl, Pal. linguiloba (Dzik), Pal. triangularis Sannemann, Pal. platys Ziegler et Sandberg, Pal. delicatula Branson et Mehl.

\section{Pechora Platform (Deulin 2006, Tsyganko 2011)}

Latest Frasnian: Ctenopolygnathus brevilamiformis (Ovnatanova), Polygnathus aequalis Klapper et Lane, P. brevis Miller et Youngquist, $P$. churkini Savage et Funai, $P$. imparilis Klapper et Lane, P. krestovnikovi Ovnatanova, P. planarius Klapper et Lane, P. politus Ovnatanova, P. unicornis Muller et Muller.

Early Famennian: Icriodus alternatus Branson et Mehl, I. cornutus Sannemann, I. iowaensis Youngquist et Peterson, Pelekysgnathus inclinatus Thomas, Mehlina sp., Polygnathus tigrinus Kuz'min et Melnikova.

North of Urals (Yudina et al. 2002, Tsyganko 2011, Ovnatanova et al. 2017, Soboleva et al. 2018)

Latest Frasnian: Polygnathus decorosus Stauffer, Palmato- lepis subrecta Miller et Youngquist, Pal. hassi Muller et Muller, Pal. bogartensis (Stauffer), Pal. timanensis Klapper, Kuz'min, Ovnatanova, Pal. kireevae Ovnatanova, Pal. juntianensis Han, Pal. nasuta Muller, Pal. rhenana Bischoff, Pal. mucronata Klapper, Kuz'min et Ovnatanova, Pal. brevis Ziegler et Sandberg, Pal. ederi Ziegler et Sandberg, Pal. linguiformis Muller, Pal. semichatovae Ovnatanova, Pal. boogardi Klapper et Foster, Ancyrodella sp. (originally diagnosed as Ancyrodella nodosa).

Early Famennian: Icriodus alternatus Branson et Mehl, I. deformatus Hun, I. aff. I. helmsi Sandberg et Dreesen, Palmatolepis praetriangularis Ziegler et Sandberg, Pal. triangularis Sannemann, Pal. clarki Ziegler, Pal. protorhomboidea Sandberg et Ziegler, Pal. delicatula Branson et Mehl, Pal. quadrantinodosalobata Sannemann, Pal. minuta Branson et Mehl, Ctenopolygnathus brevilamiformis (Ovnatanova) (originally diagnosed as Polygnathus angustidiscus).

\section{Northern Pai-Khoi}

(Zhuravlev et al. 2015, Zhuravlev 2016)

Latest Frasnian: Polygnathus alatus Huddle.

Early Famennian: Hindeodus ancestralis (Dzik), Polygnathus delinitor Drygant, P. auriformis Drygant, P. flaccidus Helms, Mehlina lindstroemi Matveeva, Zhuravlev, Eremenko, Jablonnodus erectus Dzik, Pandorinellina sp.

\section{Northern Siberia, Taimyr Peninsula (Yolkin et al. 2006)}

Early Famennian: Palmatolepis glabra pectinata Ziegler, Pal. glabra prima Ziegler et Huddle, Pal. subperlobata helmsi Ovnatanova, Pal. subperlobata subperlobata Branson et Mehl, Pal. minuta Branson et Mehl, Pal. quadrantinodosalobata Sannemann.

\section{Lena River (Yazikov et al. 2013)}

Early Famennian: Palmatolepis triangularis Sannemann, Pal. praetriangularis Ziegler et Sandberg, Pal. regularis Cooper, Pal. sp., Icriodus alternathus alternathus Branson et Mehl, Mehlina sp., Pelekysgnathus cf. Pel. planus Sannemann.

Northeastern Siberia, western part of the Kolyma Uplift (Gagiev 2009) 
Latest Frasnian: Polygnathus webbi Stauffer, P. aff. P. incompletus Uyeno, and Uyenognathus sinuosus (Szulczewski)

Early Famennian: Polygnathus brevilaminus Branson et Mehl, P. aspelundi Savage et Funai, P. procerus Sannemann, $P$. lauriformis Dreesen et Dusar, Palmatolepis triangularis Sannemann, Pal. subperlobata subperlobata Branson et Mehl, Pal. subperlobata helmsi Ovnatanova, Pal. delicatula Branson et Mehl, Pal. clarki Ziegler.

\section{Northeastern Siberia, eastern part of the Kolyma Uplift} (Gagiev 2009)
Latest Frasnian: Palmatolepis cf. Pal. hassi Muller et Muller, Pal. "gigas" Miller et Youngquist, Pal. cf. Pal. linguiformis Muller, Pal. sp., Pal. praetriangularis Ziegler et Sandberg, Ancyrodella sp. (reported by Gagiev 2009 as Ancyrodella nodosa)

Early Famennian:Mehlina lindstroemi Matveeva, Zhuravlev, Eremenko (reported by Gagiev 2009 as Polygnathus norrisi), Pal. triangularis Sannemann, Pal. subperlobata Branson et Mehl, Pal. delicatula Branson et Mehl, Pal. clarki Ziegler, Pal. tenuipunctata Sannemann, Pal. minuta minuta Branson et Mehl, and Pelekysgnathus serratus Jentzsch.

Appendix 2. List of brachiopod taxa in the late Frasnian and early Famennian.

\section{East European Platform, Voronezh Uplift \\ (Ljaschenko 1959; new data)}

Latest Frasnian: Cyrtospirifer tribulatus Ljaschenko and Theodossia sp.

Early Famennian: Schuchertella koscharica (Nalivkin), ?Plicochonetes nanus (Verneuil), Chonopectus elcicus (Nalivkin), Donalosia multispinosa (Sokolskaja), D. koscharica (Sokolskaja), Productella herminae Frech, Paromoeopygma koscharica (Nalivkin), Ripidiorhynchus huotinus (Verneuil), Cyrtospirifer zadonicus Ljaschenko.

\section{Pechora Platform (Pershina 1962, Tsyganko 2011)}

Latest Frasnian: Gypidula askynica Nalivkin, Chonetes sp., Hypothyridina sp., Radiatrypa magnitica (Nalivkin), Desquamatia (D.) alticoliformis Rzonsnitskaya, ?Costatrypa posturalica (Markovskii in Mikryukov), Adolfia sp., Warrenella (W.) koltubanica (Nalivkin), Cyrtospirifer markovskii (Nalivkin), Theodossia katavensis (Nalivkin).

Early Famennian: Ripidiorhynchus sp., Plectorhynchella sp., Dzieduszyckia baschkirica (Tschernyschew) ?Leiorhynchus ursus (Nalivkin), Pugnax biloba (Rozman), Dmitria subrotunda (Tcherkesova), Cyrtospirifer sp.

\section{South Urals (Abramova 1999)}

Early Famennian: Athyris spiriferoides Eaton, A. globosa (Roemer), Cyrtospirifer sp., Parapugnax markovskii (Yudina).

\section{West Siberia, Kuznetsk Basin (Rzhonsnitskaya 1968)}

Early Famennian: Mesoplica cf. M. praelonga (Sowerby), M. meisteri (Peetz), Athyris angelica Hall, A. globularis Phillips, Cyrtospirifer tschernyschewi Khalfin.

\section{Norhtern Siberia, Lena River (Stolb Island) (Krylova 1959, 1962; Yazikov et al. 2013)}

Latest Frasnian: Retichonetes cf. R. armatus (BouchardChantereaux in de Verneuil), Athyris sp., Mucrospirifer ex gr. mucronatiformis (Khalfin), Cyrtospirifer sp., Adolfispirifer jeremejewi (Tschernyschew), Theodossia ex gr. Th. anossofi (Verneuil).

Early Famennian: Mesoplica cf. M. meisteri (Peetz), Productella sp., ?Evanescirostrum lenense Baranov, Parapugnax cf. P. markovskii (Yudina), Athyris sp., Cyrtospirifer cf. C. tschernyschewi Khalfin, Mucrospirifer sp.

Northeastern Siberia (Alekseeva 1967, Alekseeva et al. 1996)

Latest Frasnian: Productella sp., Spinatrypina (Exatrypa) orientalis Alekseeva et Komarov, Theodossia yakutica Sidjachenko.

Early Famennian: Schuchertella sp., Plicatifera sp., Momarhynchus indigiricus Baranov et Sartenaer, Trifidorostellum aldanicum Alekseeva, Cyrtospirifer tschernyschewi Khalfin, Cyrtospirifer settedabanicus Sidjachenko, Cyrtospirifer communis Sidjachenko, ? C. zadonicus Ljaschenko. 